\title{
Cancer immunotherapy: A comprehensive appraisal of its modes of application (Review)
}

\author{
MIRA HOTEIT ${ }^{*}$, ZEINA ONEISSI $^{*}$, RANIM REDA* , FADI WAKIM ${ }^{*}$, AMAR ZAIDAN*, \\ MOHAMMAD FARRAN, ELIE ABI-KHALIL and MIRVAT EL-SIBAI
}

Department of Natural Sciences, School of Arts and Sciences, Lebanese American University, Beirut 1102 2801, Lebanon

Received January 28, 2021; Accepted June 18, 2021

DOI: 10.3892/ol.2021.12916

\begin{abstract}
Conventional cancer treatments such as chemotherapy and radiation therapy have reached their therapeutic potential, leaving a gap for developing more effective cancer therapeutics. Cancer cells evade the immune system using various mechanisms of immune tolerance, underlying the potential impact of immunotherapy in the treatment of cancer. Immunotherapy includes several approaches such as activating the immune system in a cytokine-dependent manner, manipulating the feedback mechanisms involved in the immune response, enhancing the immune response via lymphocyte expansion and using cancer vaccines to elicit long-lasting, robust responses. These techniques can be used as monotherapies or combination therapies. The present review describes the immune-based mechanisms involved in tumor cell proliferation and maintenance and the rationale underlying various treatment methods. In addition, the present review provides insight into the potential of immunotherapy used alone or in combination with various types of therapeutics.
\end{abstract}

\section{Contents}

1. Introduction

2. Cytokines in cancer immunotherapy

3. Immune checkpoint inhibitors

4. Adoptive cell transfer

5. Cancer vaccines: Types and therapeutic combinations

6. Monoclonal antibodies in immunotherapy (IT)

7. Conclusions

Correspondence to: Professor Mirvat El-Sibai, Department of Natural Sciences, School of Arts and Sciences, Lebanese American University, 303 Sage Building, Koraytem Street, Beirut 1102 2801, Lebanon

E-mail: mirvat.elsibai@lau.edu.lb

${ }^{*}$ Contributed equally

Key words: cytokines, immune checkpoint inhibitors, adoptive cell transfer, vaccines, monoclonal antibodies

\section{Introduction}

Advances in chemotherapy and radiation therapy since the second half of the 20th century have been invaluable in the effective treatment of a number of types of tumor. However, these therapeutic approaches have largely reached their potential, and any improvement in therapeutic outcomes has to involve novel, more effective therapeutic approaches (1). In recent decades, cancer immunotherapy has emerged as a promising therapeutic approach for the effective treatment of various tumors including but not limited to breast cancer, colorectal cancer and pancreatic cancer $(2,3)$. Intricately organized, the immune system consists of several components that are capable of recognizing and reacting to foreign pathogens, such as lymphoid organs, B and $\mathrm{T}$ cells and cytokines, such as interferons and colony stimulating factors (4). The cells of the immune system are widely distributed, localizing in the lymph nodes as well as other tissues and organs (4). However, the fight against cancer is complex, as cancer cells have been demonstrated to employ several mechanisms of immune tolerance. Tumors form immune-suppressive microenvironments through the presence of T regulatory cells (Tregs) or suppressive myeloid cells, allowing them to evade the immune system (5). The presence of Tregs and suppressive myeloid cells in the tumor microenvironment supports the hypothesis that the immune targeting of cancer is a viable treatment option $(1,5)$. In addition, the number of available immunotherapy options is an advantage when it comes to cancer therapy due to the variations that occur in various tumor types. One major limitation that cancer immunotherapy presents that certain treatments, such as cancer vaccines and adoptive cell are characterized by high inter-patient variability (6). Thus, such treatment may not be considered universal, and may be effective for only a subgroup of patients. The present review discusses the following immunotherapy approaches: The use of cytokines, adoptive cell transfer, immune checkpoint inhibitors (ICIs), vaccines and monoclonal antibodies. The different subtypes of checkpoint inhibitors and vaccines have been tabulated in Tables I and II, respectively. In addition, various immunotherapeutic approaches are evaluated, and the potential use of combination therapy is assessed. The immunotherapy drugs and techniques available in the market were summarized in Table III. 


\section{Cytokines in cancer immunotherapy}

Cytokine immunotherapy is an important area of cancer immunotherapy that functions by activating the immune system of patients with cancer (7). The interleukin-2 (IL-2) family of cytokines, also termed the $\gamma$-chain cytokine family, comprises IL-2, IL-7, IL-15 and IL-21, and is the most targeted cytokine family in cancer immunotherapy (7). The concept that the immune system may eradicate cancer through the function of cytokines was first studied in patients with metastatic melanoma and renal cancer (7). The IL-2 family of cytokines activates cytotoxic $\mathrm{T}$ cells $\left(\mathrm{CD} 8^{+}\right)$and natural killer (NK) cells through the activation of STAT5, which acts as a key transcription factor in pathways responsible for cellular differentiation (7). In addition, IL-2 has been demonstrated to serve an important role not only in the activation of the immune response, but also in the suppression of excessive immune reactions such as autoimmunity through the activation of $\mathrm{CD}^{+}$and Foxp3 $3^{+}$regulatory T cells (8). This part of the review focuses on the antitumor immune effects of cytokines, specifically the IL-2 family, and highlights the side effects of using cytokine immunotherapy.

IL-2 family of cytokines. The IL-2 family of cytokines has been extensively studied in the field of cancer immunotherapy (9). IL-2 is produced by antigen-activated $\mathrm{CD} 4^{+}$ T cells, CD8 ${ }^{+} \mathrm{T}$ cells, NK cells and NKT cells (9). IL-2 serves roles in the regulation, proliferation and activation of Tregs, $\mathrm{CD}^{+}{ }^{+}$and $\mathrm{CD}^{+} \mathrm{T}$ cells, B cells, mature dendritic cells (DCs) and endothelial cells (9). The main challenge in using IL-2 in immunotherapy lies in the differential expression of the IL-2 $\alpha$ receptor (IL-2R $\alpha$ ) on various types of cells, as IL-2 affects peripheral Tregs $\left(\mathrm{CD} 25^{+}, \mathrm{CD}^{+}\right.$and Foxp $\left.3^{+}\right)$more efficiently than effector $\mathrm{T}$ cells (CD8 ${ }^{+}$and NK cells) (10). IL-2R $\alpha$ and IL-2R $\beta \gamma$ are constitutively expressed on Tregs at high levels (10). This allows Tregs to respond to low doses of IL-2 in order to prevent autoimmune pathologies, and thus suppress the immune response (9). By contrast, $\mathrm{CD}^{+}, \mathrm{CD}^{+}$and $\mathrm{NK}$ cells respond only to high doses of IL-2 due to the transient expression of the receptor, which is regulated by multiple transcription factors including nuclear factor of activated $\mathrm{T}$ cells, NF- $\mathrm{kB}$ and activator protein 1 (10). The key for using cytokines in cancer treatment lies in increasing the antitumor activity of $\mathrm{CD}^{+} \mathrm{T}$ cells and NK cells, while counteracting the immunosuppressive activity of regulatory $\mathrm{T}$ cells that can hinder the response of the effector cells (10).

IL-2/IL-2R $\alpha$ fusion protein. High doses of IL-2 have been demonstrated to increase the activity of low-IL-2 affinity cells $\left(\mathrm{NK}\right.$ and $\left.\mathrm{CD}^{+}\right)$and to initiate an antitumor response (11). However, this response is largely suppressed and counteracted by the increased activity of Tregs; a response rate of only $12.5 \%$ was observed in patients with metastatic cancer who received successive high doses of IL-2 (11). On the other hand, low doses of IL-2 activate the high-affinity receptors present only in Tregs, thus preventing the activation of the antitumor immune response (11). As a result, previous studies have used varying approaches to eliminate the counteraction of Tregs on the activation of effector T cells and NK cells. One of the main approaches involves using the ALKS 4230 protein, a fusion protein of the circularly permutated IL-2 and the extracellular domain of IL-2R $\alpha$ (12). This method targets IL-2 to the intermediate-affinity receptors expressed by $\mathrm{NK}$ and $\mathrm{CD} 8^{+}$cells and not the high-affinity receptors expressed by immunosuppressive cells (12). A previous study has demonstrated that ALKS 4230 lowers the frequency of toxicity incidents occurring in patients undergoing a high-IL-2 dosage regimen and improves the antitumor efficacy by counteracting the immunosuppressive pathway (12). ALKS4230 is currently being considered as a potential cancer immunotherapy treatment (12). Other immunotherapy approaches focus on using IL-21 rather than IL-2 (12). IL-21 has been demonstrated to activate NK cells, while poorly activating $\mathrm{T}$ cells, including Tregs; IL-21 does not promote the proliferation and activation of $\mathrm{CD}^{+}, \mathrm{CD} 25^{+}$and $\mathrm{Fox}^{+}$cells nor the secretion of IL-2 (13). In the absence of IL-2, IL-21 is unable to compensate for IL-2 by maintaining the production and activation of Tregs (13). However, IL-21 is capable of promoting the proliferation of $\mathrm{NK}$ and $\mathrm{CD} 2^{+} \mathrm{T}$ cells (13). Thus, IL-21 indirectly counteracts the immunosuppressive effect of Tregs, while maintaining the proliferation of NK and effector T cells (13). IL-21 has been demonstrated to be relatively safe and tolerated, in contrast to IL-2 treatment, which leads to Vascular Leak Syndrome (13).

Polyethylene glycol (PEG)-modified IL-2. The serum half-life of IL-2 is only $7 \mathrm{~min}$; thus, for effective treatment, patients would have to receive a high dose of IL-2 every $8 \mathrm{~h}$ (14). However, due to the presence of high-affinity IL-2 receptors on endothelial cells, consecutive high doses of IL-2 may lead to toxicity including capillary leak syndrome, which causes a sudden drop in blood pressure that can potentially lead to organ failure and death (14). To solve this issue, a number of studies have examined the impact of the conjugation of IL-2 to PEG polymers on its serum half-life. PEGylated IL-2 (PEG-IL-2) has been demonstrated to have the same activity as IL-2, but with a $200 \%$ increase in circulating half-life (14). Addition of Polyethylene glycol to IL-2 increases its retention by protecting it from enzymatic digestion and renal clearance, thus increasing its serum half-life to 1 day (14). In a study where patients treated with two cycles of high dose unconjugated IL-2 were compared with patients receiving a hybrid regimen combining an initial high dose of IL-2 with successive weekly doses of PEG-IL-2, the results revealed that the relative response rate to unconjugated IL-2 was 19\%, compared with $17 \%$ for the combination of IL-2 and PEG-IL-2 combination (14). Thus, the use of high-dose IL-2 followed by PEG-IL-2 is a well-tolerated regimen that decreases the side effects of constant high IL-2 doses, but has no significant effects on the antitumor activity compared with high IL-2 dosages in patients with renal cell cancer and metastatic melanoma (14).

IL-2 in combination therapy. IL-2 cancer therapy has been studied as a monotherapy and in combination with other therapeutic approaches including chemotherapy, peptide vaccines and other combinations of cytokines (15). IL-2 immunotherapy has been approved by the US FDA for the treatment of solid tumors such as metastatic renal cancer and melanoma. In a study where patients were administered a high dose of 
Table I. Classes of immune checkpoints, their modes of action, inhibitors, types of cancer they target and the associated cardiac adverse effects (49).

\begin{tabular}{|c|c|c|c|c|}
\hline $\begin{array}{l}\text { Inhibitory } \\
\text { receptor }\end{array}$ & Mode of action & $\begin{array}{l}\text { Checkpoint } \\
\text { inhibitors }\end{array}$ & Types of cancer treated & Cardiac effects \\
\hline CTLA-4 (on T cells) & $\begin{array}{l}\text { Interacts with HLA-B7-1 and } \\
\text { HLA-B7-2 on T cells and } \\
\text { delivers an inhibitory signal to } \\
\text { effector T cells while promoting } \\
\text { inhibitory function of regulatory } \\
\text { T cells }\end{array}$ & Ipilimumab & $\begin{array}{l}\text { Advanced melanoma, } \\
\text { advanced renal cell cancer }\end{array}$ & $\begin{array}{l}\text { Immune-related } \\
\text { myocarditis, } \\
\text { Takotsubo-like } \\
\text { syndrome, } \\
\text { smoldering } \\
\text { myocarditis }\end{array}$ \\
\hline \multirow[t]{2}{*}{ PD-1 (on T cells) } & $\begin{array}{l}\text { PD-L1 is expressed on the tumor } \\
\text { cell surface and through } \\
\text { interaction with PD- } 1 \text { on T cells } \\
\text { causes apoptosis of cytotoxic } \\
\text { T cells while inhibiting } \\
\text { apoptosis of regulatory T cells }\end{array}$ & Nivolumab & $\begin{array}{l}\text { Melanoma, Hodgkin } \\
\text { lymphoma, NSCLC, kidney } \\
\text { cancers }\end{array}$ & $\begin{array}{l}\text { Acute lymphocytic } \\
\text { myocarditis, heart } \\
\text { failure, cancer, } \\
\text { head and neck } \\
\text { complete } \\
\text { atrioventricular } \\
\text { block }\end{array}$ \\
\hline & & Pembrolizumab & $\begin{array}{l}\text { Melanoma, Hodgkin } \\
\text { lymphoma, NSCLC, } \\
\text { cancers of the urinary tract }\end{array}$ & $\begin{array}{l}\text { Myocarditis, } \\
\text { polymyositis }\end{array}$ \\
\hline \multirow[t]{3}{*}{ PD-L1 (on cancer cells) } & & Atezolizumab & $\begin{array}{l}\text { Lung cancer, liver cancer, } \\
\text { breast cancer, urothelial } \\
\text { cancer }\end{array}$ & $\begin{array}{l}\text { Myositis with } \\
\text { myasthenic } \\
\text { syndrome }\end{array}$ \\
\hline & & Avelumab & $\begin{array}{l}\text { Merkel cell carcinoma, } \\
\text { cancers of the urinary tract }\end{array}$ & $\begin{array}{l}\text { Immune-related } \\
\text { myocarditis, } \\
\text { hypertension }\end{array}$ \\
\hline & & Durvalumab & NSCLC & $\begin{array}{l}\text { Immune-related } \\
\text { myocarditis }\end{array}$ \\
\hline
\end{tabular}

CTLA-4, cytotoxic T lymphocyte associated protein 4; PD-1, programmed cell death protein 1; PD-L1, programmed cell death ligand 1; NSCLC, non-small cell lung cancer.

IL-2 (600,000-720,000 IU/kg) every $8 \mathrm{~h}$, the overall response rate was $15 \%$, with a complete response rate of $7 \%$ (16). Another study used IL-2 in combination with lymphokine activated killer (LAK) cells, and an overall response rate of 25-30\% was observed (16). A subsequent study focused on combining ex vivo expanded tumor infiltrating lymphocytes (TILs) with a high-dose IL-2 regimen and lymphodepletion for the treatment of patients with metastatic melanoma (17). In this approach, TILs were rapidly expanded in the presence of anti-CD3, feeder cells and IL-2, and infused into the patients, and an overall response of $50 \%$ was reported in patients with metastatic melanoma (17).

Drawbacks of IL2 therapy. The effective use of IL-2 in cancer treatment is hampered by several drawbacks, the main one being its short serum half-life, which is mostly due to rapid metabolism and elimination by the kidneys (18). Thus, IL-2 has to be administered repeatedly (every $8 \mathrm{~h}$ ) at high doses, which can lead to severe toxicity such as hypotension, cardiac problems and pulmonary edema (18). In addition, Krieg et al (18) have reported that the binding of IL-2 to high-affinity IL-2Ra-expressing endothelial cells causes acute vasodilation effects that, in turn, lead to the development of vascular leak syndrome.
Cytokines in combination therapy. Cytokines are a diverse group of molecules, each of which can be used to target specific cells and activate unique pathways to obtain an overall therapeutic effect. Cytokines can also be combined with other therapeutic agents that work synergistically in order to provide significant advantages over monotherapy (19). Ovarian cancer is a type of cancer in which combination immunotherapy has shown promising results; one of the emerging therapies for ovarian cancer is targeting its arginine auxotrophy by depriving it of arginine, using a recombinant human arginase, inducing autophagy and subsequenT cell death (19). On the other hand, combination immunotherapy has also been effective in the treatment of ovarian cancer. A study by Ingersoll et al has demonstrated that combining cellular therapy using peripheral blood mononuclear cells with IL-2 and IFN cytokines significantly increases the survival of an ovarian cancer xenograft mouse model (20). This is consistent with another study that has reported that such a combination also exhibited increased cytotoxic effects on two ovarian cancer cell lines compared with those of monotherapy (21). Additionally, combining interferon $\alpha-2 b$ and interleukin-2 cytokine treatment with adoptive cell transfer and cryosurgery has demonstrated promising results in patients with advanced oral mucosa melanoma (21). 
Table II. Types of cancer vaccines.

\begin{tabular}{|c|c|c|c|c|c|c|}
\hline $\begin{array}{l}\text { Type of } \\
\text { vaccine }\end{array}$ & Mode of action & $\begin{array}{l}\text { Immune } \\
\text { response }\end{array}$ & Manipulation & Key advantage & Key limitation & Cost \\
\hline DNA & $\begin{array}{l}\text { Bacterial plasmid } \\
\text { encoding tumor antigen } \\
\text { coupled to a eukaryotic } \\
\text { promoter (89) }\end{array}$ & Poor (95) & Easy (93) & $\begin{array}{l}\text { CpG islands and } \\
\text { post-translational } \\
\text { modification in } \\
\text { hosT cell (95) }\end{array}$ & $\begin{array}{l}\text { Low uptake rate of } \\
\text { plasmid (94) }\end{array}$ & Cheap (93) \\
\hline Peptide & $\begin{array}{l}\text { Nongenetic component } \\
\text { that induces an immune } \\
\text { response (98) }\end{array}$ & Poor (100) & Easy (99) & $\begin{array}{l}\text { Do not overload the } \\
\text { immune system (99) }\end{array}$ & $\begin{array}{l}\text { Inconclusive safety } \\
\text { of vaccine when used } \\
\text { with adjuvants (99) }\end{array}$ & Cheap (99) \\
\hline $\begin{array}{l}\text { Dendritic } \\
\text { cell }\end{array}$ & $\begin{array}{l}\text { Patient dendritic cells } \\
\text { transfected with the } \\
\text { tumor antigen }(106,118)\end{array}$ & Strong (107) & - & Personalization (107) & $\begin{array}{l}\text { Limitations of } \\
\text { monocyte-derived } \\
\text { dendritic cells (109) }\end{array}$ & $\begin{array}{l}\text { Expensive } \\
\text { (109) }\end{array}$ \\
\hline $\begin{array}{l}\text { Whole } \\
\text { cell }\end{array}$ & $\begin{array}{l}\text { Modified whole tumor } \\
\text { cells (114) }\end{array}$ & $\begin{array}{l}\text { Strong with the } \\
\text { exception of } \\
\text { advanced } \\
\text { tumors (108) }\end{array}$ & Easy (114) & $\begin{array}{l}\text { Expression of TSAs } \\
\text { and TAAs (115) }\end{array}$ & $\begin{array}{l}\text { Immune evasion } \\
\text { (114) }\end{array}$ & $\begin{array}{l}\text { Expensive } \\
(108)\end{array}$ \\
\hline
\end{tabular}

TSAs, tumor-specific antigens; TAAs, tumor-associated antigens.

Other interleukins and cytokines in immunotherapy. IL-2 has been extensively studied in renal cancer and melanoma; however, other interleukins are also emerging in the field of cancer immunotherapy (16). Interleukins such as IL-15, IL-10 and IL-21 are of major importance in cancer immunotherapeutic studies (7). IL-5 binds to the same receptor as IL-2 and activates STAT5 (7). However, IL-5 initiates a different downstream signaling pathway, which has different effects on $\mathrm{CDC}^{+}$cell differentiation and memory cell formation (3).

IL-15 is crucial for the proliferation and maintenance of memory $\mathrm{T}$ cells as well as for promoting the survival and increasing the cytotoxicity of $\mathrm{NK}$ and $\mathrm{CD} 8^{+} \mathrm{T}$ cells (22). IL-15 also induces the release and proliferation of other proinflammatory cytokines such as IFN $-\gamma(22)$. Notably, IL-15 has no affinity for the IL-2R $\alpha$ chain (CD25) and thus does not activate Tregs (22). As a result, IL-15 has been extensively studied as an alternative of IL-2 in cancer immunotherapy. For example, in a recent clinical trial, patients with renal cell carcinoma, non-small cell lung cancer (NSCLC) and melanoma received subcutaneous IL-15 injections, and the results demonstrated a dose-dependent increase in the number of active NK cells (23). In addition, a number of patients exhibited marked disease stabilization, especially patients with renal cell carcinoma, who presented with $>2$ years of increased disease stability (23). However, one study reported that IL-15 has a very short serum half-life of only $2.5 \mathrm{~h}$ due to its small size, resulting in rapid elimination from circulation (24). In addition, high doses of IL-15 have deleterious effects on the lymphocytes (22). Thus, trans-presentation has been adopted as a solution for this issue by increasing the specificity of IL-15 and increasing its half-life (25).

IL-15 binds to the high-affinity IL-15 receptor IL-15R $\alpha$ on the cell surface, which stimulates IL-15 signaling in the neighboring cells (26). This process is of great importance in activating the cytotoxic immune response and has been studied as an approach to stimulate direct cytokine delivery to responsive cells (26).

Several studies have focused on engineering IL-15 variants with a longer half-life (27-29). One of the promising fusion proteins includes the RNase L inhibitor protein, where IL-15 is fused to the binding domain of IL-15R $\alpha$, also termed the sushi domain (27). This fusion protein was shown to increase the survival of mice bearing multiple myeloma (29). Another study focused on constructing a triple-fusion protein termed Sushi-IL15-Apo (28). The Sushi-IL15-Apo protein comprises the fusion of human IL-15 to the sushi domain and to apolipoprotein A-I (28). The receptor of the apolipoprotein A-I is expressed at high levels in tumor cells, and thus IL-15 activity can be specifically targeted to tumor cells (28).

Another fusion protein of IL-15 is ALT-803, in which IL-15 is fused to the sushi domain and an IgG1 Fc domain (29). A study in mice has reported that this fusion protein successfully promotes IL-2 activity (29). In a dose-escalation phase I clinical study, patients with hematological cancer received ALT-803 following relapse in response to the allotransplantation of bone marrow (30). Treatment with the fusion protein was well-tolerated in all patients, and the results demonstrated increased numbers of $\mathrm{NK}$ and $\mathrm{CD} 8^{+}$cells (30). Another study has reported that ALT-803 in combination with intravesical bacillus Calmette-Guérin therapy exhibited sustained and complete responses in nine patients with localized bladder cancer; as a result, this combination treatment was approved by the FDA for non-muscle invasive bladder cancer (31). A study investigated the use in IL-15 in combination therapies and as an adjuvant in T- or NK-cell therapies (31).

Another cytokine from the IL-2 family is IL-21, which exerts poor effects on the activation of Tregs, but is considered a potent driver of NK cell activation and proliferation (7). 
Table III. Immunotherapy drugs and techniques available in the market.

\begin{tabular}{|c|c|c|c|c|}
\hline Drug & Type & Description & Type of cancer & Combination therapy \\
\hline $\begin{array}{l}\text { IMYGLIC or } \\
\text { T-VEC }\end{array}$ & Vaccine (133) & $\begin{array}{l}\text { Modified HSV1 that replicates in } \\
\text { recurrent lesions causing cell } \\
\text { lysis and death (133) }\end{array}$ & Melanomas (133) & \\
\hline $\begin{array}{l}\text { Sipleucel-T or } \\
\text { PROVENGE }\end{array}$ & Vaccine (112) & $\begin{array}{l}\text { Personalized dendritic cell vaccine } \\
\text { for which the patienT cells are } \\
\text { harvested and modified to express } \\
\text { tumor antigens in MHC I and II (112) }\end{array}$ & $\begin{array}{l}\text { Metastatic castration-resistant } \\
\text { prostate cancer }(112)\end{array}$ & \\
\hline Rituximab & $\begin{array}{l}\text { Monoclonal } \\
\text { antibody (125) }\end{array}$ & $\begin{array}{l}\text { Induces tumor cell death through } \\
\text { two mechanisms centered on Fc (125) }\end{array}$ & $\begin{array}{l}\text { CD20+ B-cell non-Hodgkin } \\
\text { lymphoma }(125)\end{array}$ & \\
\hline Trastuzumab & $\begin{array}{l}\text { Monoclonal } \\
\text { antibody (125) }\end{array}$ & $\begin{array}{l}\text { Induces tumor cell death through } \\
\text { two mechanisms centered on Fc (125) }\end{array}$ & HER2 ${ }^{+}$breast cancer $(125)$ & \\
\hline Cetuximab & $\begin{array}{l}\text { Monoclonal } \\
\text { antibody (128) }\end{array}$ & $\begin{array}{l}\text { Induces tumor cell death through } \\
\text { two mechanisms centered on Fc (125) }\end{array}$ & $\begin{array}{l}\text { Head and neck squamous } \\
\text { cell carcinoma (128) }\end{array}$ & $\begin{array}{l}\text { Enhanced when } \\
\text { combined with } \\
\text { inhibitors of immune } \\
\text { checkpoints such as } \\
\text { anti PD-1 } \\
\text { antibodies and } \\
\text { pembrolizumab (128) }\end{array}$ \\
\hline Pembrolizumab & $\begin{array}{l}\text { Monoclonal } \\
\text { antibody (128) }\end{array}$ & $\begin{array}{l}\text { Induces tumor cell death through } \\
\text { two mechanisms centered on Fc (125) }\end{array}$ & $\begin{array}{l}\text { Advanced HER2 }{ }^{+} \\
\text {breast cancer }(128)\end{array}$ & \\
\hline Nivolumab & $\begin{array}{l}\text { Monoclonal } \\
\text { antibody (130) }\end{array}$ & $\begin{array}{l}\text { Induces tumor cell death through } \\
\text { two mechanisms centered on Fc (125) }\end{array}$ & Metastatic NSCLC (130) & $\begin{array}{l}\text { Combined with } \\
\text { engineered } \\
\text { PEGylated IL-2 (130) }\end{array}$ \\
\hline Atezolizumab & $\begin{array}{l}\text { Monoclonal } \\
\text { antibody (130) }\end{array}$ & $\begin{array}{l}\text { Induces tumor cell death through } \\
\text { two mechanisms centered on Fc (130) }\end{array}$ & NSCLC (130) & $\begin{array}{l}\text { Potential advantage } \\
\text { when combined with } \\
\text { PEGylated IL-2 (130) }\end{array}$ \\
\hline
\end{tabular}

HSV1, herpes simplex virus 1; MHC, major histocompatibility complex; NSCLC, non-small cell lung cancer; PEG, polyethylene glycol.

IL-21 has been studied alone and in combination therapies in cancer trials $(7,32)$. In a study of the combination therapy of IL-21 with rituximab in patients with non-Hodgkin lymphoma, eight out of 19 patients presented with promising clinical responses (32). However, clinical trials with IL-21 are still minimal, and future studies are required that focus on its use in combination therapy.

Anti-inflammatory cytokines such as IL-10 are also a major subject of cancer immunotherapy studies. Although IL-10 inhibits the cytokine release in T and NK cells, a previous study has highlighted that IL-10 inhibits antigen-induced apoptosis of cytotoxic $\mathrm{T}$ cells $\left(\mathrm{CD}^{+}\right)$ in cases of chronic infections and tumors (33). This was demonstrated in a phase I clinical trial of patients treated with PEG-conjugated IL-10; the results were promising, with only $15 \%$ of patients presenting with grade 3 immune adverse effects and PEG-IL-10 being well tolerated in the majority of the patients (33). The current focus is on the use of IL-10 in combination therapy with vaccines or other chemotherapeutic agents (34).

A number of other cytokines, including IFN- $\alpha$ and TNF- $\alpha$, have been extensively studied in cancer immunotherapy. In 1986, IFN- $\alpha$ was approved by the FDA for the treatment of patients with hairy cell leukemia (35). Since then, it has been a candidate for the treatment of solid tumors and other hematological malignancies at high doses (35). A major study has demonstrated that high doses of IFN- $\alpha$ trigger apoptosis and inhibit the proliferation of cancer cells (35).

Similar to other cytokines, extending the serum half-life of IFN- $\alpha$ has also been achieved through PEGylation (36). PEG-IFN- $\alpha$ has been approved as an adjuvant in the treatment of melanoma (36). A previous study focusing on IFN- $\alpha$ in combination therapies has reported that IFN- $\alpha$ increases patient survival rates by enhancing the antitumor responses of cytotoxic chemotherapies (37). However, the issue with IFN- $\alpha$ is that high doses induce autoimmune responses due to its role in potentiating dendritic cells, which induce cross-priming of apoptotic antigens to cytotoxic T cells (38). One method to overcome the cytotoxic activity of IFN- $\alpha$ and only provoke the immune-stimulatory activity involves the fusion of IFN- $\alpha$ to apolipoprotein A-I (39). Apo-IFN- $\alpha$ exhibits an increased half-life, enhanced immunostimulatory activity and tumor targeting, as well as decreased cytotoxicity compared with those of IFN- $\alpha$ (39).

Other approaches to overcome the cytotoxicity of IFN- $\alpha$ focus on fusing a mutated IFN- $\alpha$ with reduced affinity for its receptor to a cell-specific targeting domain C-type lectin 
domain-containing 9A, which is a molecule expressed on cross-priming specialized dendritic cells (40). The mutated cytokines termed activity-on-target cytokines, or AcTakines, exhibit strong antitumor activity in lymphoma, breast carcinoma and melanoma in humanized mice with no side effects (40).

Another cytokine that may be used as a potential cancer therapeutic is the TNF- $\alpha$. This pro-inflammatory cytokine is secreted mainly by antigen-presenting cells such as monocytes, macrophages and DCs, as well as by other cell types such as endothelial cells, fibroblasts and adipocytes under acute inflammation and stress conditions (41). TNF- $\alpha$ was the first cytokine studied for cancer immunotherapy (41). Numerous studies have focused on the tumor cell apoptosis and antitumor activity of TNF- $\alpha$ in various malignancies, such as AIDS-associated Kaposi's sarcoma (41-44). Phase I clinical trials of TNF- $\alpha$ have revealed dose-limiting toxicities such as nausea, vomiting, anorexia, hypotension and thrombocytopenia, with little to no tumor response (42). Chronic TNF- $\alpha$ exposure also induced the cell death of T lymphocytes and, as a result, promoted tumor growth (43).

Considering the range of toxicities observed in animal studies, the antitumor efficacy of TNF- $\alpha$ in humans was not evident; however, a number of studies described the localized administration of TNF- $\alpha$ in patients as an approach to avoid the toxicities associated with its systemic use (44-46). In a study on localized intratumoral administration of TNF- $\alpha$ to patients with Kaposi's sarcoma, the results demonstrated a reduction in the cancer lesions in 15 out of 16 patients (44).

A clinically successful approach of TNF- $\alpha$ therapy is its use in combination with the alkylating agent melphalan in isolated limb perfusion protocols (45). This combination therapy approach has also been adopted for patients with soft tissue sarcomas and melanomas and has exhibited an $80 \%$ complete response rate (45). The high response rates were associated with increased endothelium permeability, facilitating the diffusion of chemotherapy into the tumor and the direct killing of the tumor endothelium (45). In addition, tumor vascular collapse and hemorrhagic necrosis were observed upon TNF- $\alpha$ and melphalan administration (46). TNF- $\alpha$-ILP therapy was approved for high-grade soft tissue carcinoma treatment in Europe in 1998 (47).

Cytokines are potent yet complex immune mediators that still require extensive research. Future research should focus on two main approaches in cytokine therapies: Limiting the effects of cytokines at the site of tumor to avoid systemic inflammatory side effects and studying the efficacy of these treatments in combination therapies.

\section{Immune checkpoint inhibitors}

With the increasing understanding of cancer immunology, researchers have been able to develop novel promising forms of immunotherapy. For instance, strategies involving the negative regulation of the immune system have been demonstrated to exhibit antitumor activity across a wide range of solid tumors, such as NSCLC and advanced melanoma (48). ICIs are the driving force of this negative regulation (48).

$\mathrm{T}$ cells express receptors to which antigens and other ligands bind, leading to either their functional activation or inhibition depending on the type of T-cell receptor targeted, which is a process based on immune checkpoints (48). Immune checkpoint-related mechanisms are targeted by cancer cells, allowing them to escape the immune system through negative feedback mechanisms (48). This is achieved by binding of the cancer cell to inhibitory receptors on $\mathrm{T}$ cells, specifically the cytotoxic T lymphocyte associated protein 4 (CTLA-4) and programmed cell death protein 1 (PD-1) inhibitory receptors (48). As the antigen-presenting cancer cells bind to these receptors, they arrest T-cell activation and proliferation, thus weakening the immune response against the tumor (48).

A major turning point in cancer immunotherapy has been the clinical application of antibodies that block immune checkpoints (48). These antibodies are collectively referred to as the ICIs. The main goal of ICIs is to induce immune cell proliferation and activation against cancer cells by stimulating the immune system (48). This section of the current review combines the results of previous studies to provide an overview on the types of ICIs used in either monotherapy or combination therapy in various types of cancer. The outcomes and adverse events (AEs) of ICI therapy as well as the possibility of overcoming these AEs are also discussed. Table I summarizes the classes of immune checkpoints, their modes of action, inhibitors, types of cancers they target and the associated cardiac adverse effects (49).

ICIs in advanced melanoma. Numerous studies have tested the efficacy and biological effects of CTLA-4 and PD-1 blockage through either monotherapy or combined therapy. For instance, to test for the efficiency of ICIs in advanced melanoma, Wolchok et al (50) randomly treated previously untreated patients with either the anti-CTLA-4 human monoclonal antibody ipilimumab monotherapy, the anti-PD-1 antibody Nivolumab monotherapy or a combination of ipilimumab and Nivolumab. Assessment of the results was based on three variables: i) Overall survival (OS), the time from randomization of treatments until death; ii) objective response rate (ORR), the ratio of patients that exhibited partial or complete response to a specific treatment; and iii) the rate of progression-free survival (PFS), the time elapsed between randomization and the first documented disease or death (50). The results demonstrated that patients who underwent combined treatment exhibited the highest ORR (58\%), a higher rate of PFS (11.5 months) and the highest rate of OS among the three groups throughout a 3 -year analysis period (50). This was compared with a 44 and 19\% ORR, 6.9 and 2.9 months of PFS, and 52 and 34\% OS rate in patients that underwent Nivolumab and ipilimumab monotherapy, respectively (50). Therefore, for previously untreated patients with advanced melanoma, more promising results were observed using the combination therapy of Nivolumab and Ipilimumab compared with either treatment alone (50).

ICIs in NSCLC. Although NSCLC is a poorly immunogenic malignancy, ICIs may be encouraging therapeutic agents for this type of tumor, as they exhibit antitumor activity (50). As previously reported for patients with advanced melanoma, monotherapy of the anti-CTLA-1 antibody ipilimumab leads to an improvement in the OS rate (50). However, this is not the case for patients with NSCLC, unless ipilimumab is combined with other immunotherapies, such as PD-1 inhibitors (48). When patients with NSCLC were treated with both ipilimumab 
and Nivolumab using the same doses used in previous studies for the treatment of melanoma, the ORR was $16 \%$, but was accompanied by a high rate of grade 3/4 treatment-related AEs and treatment-related discontinuations (49 and 35\%, respectively) (48). However, when the doses were adjusted, increased tolerability and positive antitumor activities were observed in the patients, with the ORR of $39-47 \%$ and a decrease in the rate of treatment-related discontinuation to $13-14 \%$ (48).

ICIs for the treatment of central nervous system (CNS) metastasis. Systemic cancers are often accompanied by brain metastasis, a CNS complication which affects $20 \%$ of adults with systemic malignancies (51). These most commonly include lung cancer, melanoma and breast cancer (51). Brain metastasis is becoming more apparent as awareness about it is increasing and diagnostic techniques are improving (42).

CNS is considered to be an immune-privileged environment and, to date, treatments for brain metastasis were based on stereotactic radiosurgery, whole-brain radiotherapy and other local therapies. However, increasing knowledge regarding the lymphatic system of the CNS and the alterations of the blood-brain barrier by the tumor microenvironment suggests that it is possible for immune cells to circulate in and out of the CNS (42). Consequently, it is currently considered possible to use ICIs to trigger peripheral T cells to exert antitumor effects within the CNS (49). This is supported by the association between the high density of TILs and OS in both primary tumors and brain metastasis (42).

The first ICI to exhibit efficacy in the treatment of brain metastasis was ipilimumab; this was discovered incidentally when patients treated for metastatic melanoma also presented with durable CNS responses (51). These results were subsequently confirmed during treatments of patients with melanoma brain metastasis using ipilimumab (51). Clinical data of these studies has demonstrated improvements in ORR, CNS disease control and response rate and PFS, establishing the basis for further ICI therapy. Additionally, anti-PD1 monoclonal antibodies nivolumab and pembrolizumab have exhibited similar efficacy for previously untreated melanoma brain metastasis (51).

On the other hand, in accordance with what has been previously observed in the treatment of melanoma and NSCLC, combined therapy exhibits the most promising CNS response rates to immunotherapy (51). In one of the studies aiming to demonstrate the efficacy of combination immunotherapy for untreated patients with melanoma brain metastasis, clinical outcomes of monotherapy using nivolumab were compared with those of combined therapy with Nivolumab and ipilimumab (51). The CNS response rates were higher when patients were treated with combined therapy $(46 \%)$ compared with those observed following monotherapy (20\%), which included CNS complete response rates of 17 and $12 \%$, respectively (51). However, combination therapy was associated with high toxicity, with grade $\geq 3$ AEs observed in $63 \%$ of patients receiving Nivolumab and ipilimumab, compared with $16 \%$ of patients receiving nivolumab alone (51).

Therefore, with promising clinical results for the treatment of brain metastasis, systemic immunotherapy contradicts the paradigm of the immune-privileged brain, especially with the use of combined therapy.
Immune-related (ir)AEs of ICIs. As aforementioned, a number of studies have reported that combination therapy of anti-CTLA-1 and anti-PD-1 antibodies is more efficacious compared with the respective monotherapies $(48,50,51)$. However, the combination has also been demonstrated to increase the number and frequency of AEs (52). The most common AEs are cutaneous, including pruritus, rash and dermatitis; other AEs are gastrointestinal (mainly diarrhea and colitis), hepatic, endocrine (thyroid glands), pulmonary (most commonly pneumonitis), renal, pancreatic, neurological and rarely cardiac, including autoimmune myocarditis, heart failure, cardiomyopathy or cardiac fibrosis (52). The cardiac AEs are mostly documented among patients with history of cardiac pathologies, suggesting that these AEs represent a deterioration of existing cardiac disorders (52).

One potential cause of the apparent increase in AEs compared with each monotherapy may be the assessment of an optimal dosage regimen (53). In the treatment of patients with NSCLC, different outcomes were obtained when the administered doses of ICIs were adjusted (48). AEs may also arise from the tumor-affected organs, specifically as the disease progresses and the tumor undergoes biological changes (53). For instance, pulmonary events such as pneumonitis are more likely occur in patients with NSCLC compared with those with melanoma, whereas rashes or vitiligo are frequently observed in patients with melanoma $(54,55)$. Notably, with the exception of endocrine events which are considered irreversible and hard to manage (53), most of the other AEs can be well managed and are reversible, especially with steroid co-treatment (54). A previous study has reported that following corticosteroid administration, a patient experienced a rapid increase in the ejection fraction that had been previously reduced to $15 \%$ due to of autoimmune myocarditis (52).

Rechallenging with ICIs after irAEs. It remains unclear whether it may be safe to re-treat patients that presented with grade $\geq 2$ irAEs with ICIs. Previous studies have reported that re-treating with ICIs is feasible, but often leads to the recurrence of grade $\geq 2$ irAEs. Although no deaths were recorded, irAEs occurred on 22 out of 40 patients in one study that evaluated the effectiveness of rechallenging with ICIs after an irAE (55). Thus, re-administration of ICIs may be safe if patients are closely monitored, especially if these patients have previously achieved a complete or partial response prior to the first occurrence of an irAE in their initial treatment (56).

Assessing rechallenges remains specific to each case and to the risk-benefit ratio. For example, re-treatments may only be considered if the grades of the irAEs decrease to 0 or 1 (56). Treatment decisions also depend on the potential severity of irAE reoccurrence, especially if these are cardiac or neurological, as the tools for imaging and biological monitoring that allow estimations of future recurrence of irAEs are lacking for neurological irAEs (56).

Potential biomarkers for immunotherapy. Researchers are currently developing predictive biomarkers of treatment response, one of which is the tumor cell expression of PD-1 ligand 1 (PD-L1), which binds to the PD-1 inhibitory receptors on $\mathrm{T}$ cells $(51,57)$. The use of predictive biomarkers may allow improved patient selection for treatment and may help 
predict the extent of the response to treatment using ICIs (57). For example, in one study, patients with NSCLC with PD-L1 ${ }^{+}$ brain metastasis exhibited a higher intracranial response rate (29\%) compared with no response for patients with PD-L1 brain metastasis (51). In addition, the expression of PD-L1 differs with the type of cancer, and has been reported to be highest among patients with NSCLC and lowest in melanoma, where PD-L1 ${ }^{+}$cells were mainly non-tumor cells that were present in the tumor microenvironment (51). Furthermore, following treatment with CTLA-4/PD-1 checkpoint inhibitors, PD-L1 expression correlates with improved PFS and OS rates in NSCLC and renal cell carcinoma (57). However, $\mathrm{PD}-\mathrm{L1}^{+}$non-tumor cells exhibit a greater degree of response compared with PD-L1 ${ }^{+}$tumor cells (57). One explanation may be that macrophages and activated lymphocytes that express PD-L1 may interact with PD-1 inhibitory receptors on T cells, inhibiting their proliferative functions (57).

Therefore, numerous variables and conflicting data, including tumor type, identity of cells expressing PD-L1, various reagents and staining methods, as well as the incompatible cut-off points for determining positivity, complicate the use of PD-L1 as a predictive biomarker to assess the efficiency of treatment involving ICIs (57).

Another potential clinical biomarker for the detection and treatment assessment of brain metastasis is the tumor mutational burden (TMB). For instance, in one series of experiments, high TMB in brain metastasis was more common compared with that in primary tumors and was reported in $39 \%$ of the cases (51).

In conclusion, ICIs are a centerpiece of immunotherapy, as they exhibit antitumor activity across a range of tumor types. In addition, combined therapy with anti-CTLA-4 and anti-PD-1 antibodies results in higher rates of OS and PFS compared with those following monotherapies with either of the two ICIs. However, these high response rates are accompanied by a variety of irAEs, which are, in most types of tumor, reversible and manageable when steroids are administered. Rechallenging with ICIs following occurrence of irAEs is considered to be feasible if patients are closely monitored. Finally, further studies are needed to assess the predictive role of PD-L1 expression as a biomarker.

\section{Adoptive cell transfer}

Adoptive cell transfer (ACT) is an immunotherapy approach used in the treatment of cancer. The main objective of ACT is to enhance the function of the immune system (58). ACT is a promising immunotherapy approach for the treatment of various types of tumor, such as metastatic cancer, breast cancer, gastric cancer, colon cancer and pancreatic cancer (58). ACT is based on the transfer of lymphocytes to the patient following in vitro expansion and gene modification in order to enhance their cancer-fighting capabilities (58). In autologous cell therapy, the cells are extracted from the patient, cultured in vitro and administered to the same patient (58). By contrast, allogeneic therapies involve the transfer of cells from a donor different from the receiving patient $(59,60)$. Previous studies have reported that several cell types can be used in ACT treatment, including T lymphocytes, NK cells, DCs and stem cells $(59,60)$. In 1955, Mitchison (61) was the first to study ACT for cancer, and its therapeutic potential was first tested by Fefer and Rosenberg 45 years ago $(62,63)$. In 1998, Matsumoto demonstrated that ACT upregulated the expression of CD3 $\zeta$ in peripheral lymphocytes and improved the immune response in patients with gastric and colon cancer (64). Recent advances in cellular and molecular biology techniques have established ACT as a viable therapeutic approach for patients who are not responsive to traditional chemotherapy (59). ACT takes advantage of the natural abilities of cytotoxic $\mathrm{T}$ lymphocytes against cancer cells by binding to antigens on the surface of these cells, which has been applied in TIL, engineered T-cell receptor (TCR), chimeric antigen receptor (CAR) $\mathrm{T}$ cell and NK cell therapy (59). ACT, in combination with other treatments, is currently being evaluated in several types of cancer, such as metastatic cancer, breast cancer and melanoma in clinical trials (60).

Types of ACT. One form of adoptive cell transfer is TIL therapy, which enhances the function of the naturally occurring $\mathrm{T}$ lymphocytes; $\mathrm{T}$ cells infiltrating the tumor are harvested from the patient, activated and expanded, an infused back into the patient in order to destroy tumor cells (60).

Engineered TCR therapy is applied to patients whose T cells do not proliferate sufficiently to challenge the tumor (60). In this approach, $\mathrm{T}$ cells are harvested, activated, expanded and equipped with receptors that target specific cancer antigens that are protein, carbohydrate or glycolipid-based (60).

CAR T-cell therapy has the ability to target cancer cells even when their antigen is not bound to the surface of major histocompatibility complex (MHC) by equipping patient $\mathrm{T}$ cells with a synthetic receptor termed CAR (60). However, the range of potential antigen targets is limited, since CAR $\mathrm{T}$ cells only recognize antigens that naturally occur on cell surfaces (60). CAR T-cell therapy involves genetic modification of $\mathrm{T}$ cells harvested from patients with cancer in vitro to recognize a cancer-specific antigen (60). The engineering of $\mathrm{T}$ cells has exhibited potential in cancer therapy, especially in overcoming the limitations of TIL and TCR therapies of being unable to recognize cancer antigens unless they are expressed by MHC molecules (65). However, these modified cells do not undergo normal tolerance mechanisms, such as thymic education (60). In addition to their reactivity against target molecules, these cells may react against antigens present in healthy tissues (59). One potential solution for this toxicity is to modify the antigen specificity of $\mathrm{T}$ cells in a transient manner (59). Another strategy uses a drug-inducible suicide gene or a cell-expressed ligand that is targeted by a depleting antibody in order to allow the removal of donor T cells (59). In other approaches, the CAR activity depends on small molecule drugs, co-expression of two tumor antigens or non-expression of a non-tumor antigen (59). In addition, the use of a bi-specific antibody or a biotin-binding immune receptor in conjunction with a biotinylated molecule targeting a tumor antigen brings together lymphocytes and tumor cells, which may aid the selective and conditional antigen targeting (59).

NK cells have been incorporated in adoptive cell therapy by equipping NK cells with cancer-targeting CARs (66). NK cells are innate lymphocytes that recognize and lyse transformed or virally infected cells without prior activation (67). Adoptive cancer therapy with NK cells has been 
tested in clinical trials due to the ability of NK cells to induce antigen-independent immune responses against malignancies that are not restricted by the MHC (68). Allogeneic NK therapy has an advantage against autologous T cell ACT due to a favorable therapeutic and safety profile, suggesting that NK cells may be a suitable alternative for CAR-based therapies (69). Cancer treatment-induced immune defects associated with the use of patient-derived immune cells may be avoided by using NK cells obtained from healthy donors (68). In addition, NK cells recognize cancer cells and trigger tumor lysis by expressing various endogenous activating receptors (68). CAR-expressing NK cells function even when the CAR target antigens are downregulated in cancer cells during treatment (68). Additionally, in contrast to T cells, NK cells do not produce autocrine growth factors such as IL-2, which limits their lifespan; therefore, NK cells do not remain in circulation, reducing the risk of long-term AEs and eliminating the need for introducing suicide genes (68). NK cells have also been reported to not induce graft-versus-host disease or other types of alloimmune or autoimmune toxicity, allowing versatile cellular immunotherapy with allogeneic NK cells from healthy donors (68).

Factors that determine the effectiveness of ACT. Several factors appear to be important for the effectiveness of ACT therapy including cell dose, cytolytic effector function and the long-term persistence of transferred cells (70). The latter is associated with a minimal differentiated phenotype, which maintains the capacity of producing a continuous supply of cytolytic effector progeny (70). The quality of the transduced cells that are administered to the patient is also of great importance, and this area has been extensively studied (70). Lowering the dose of IL-2 added to the cells and reducing the time that the transduced cells spend in culture (between 5 and 7 days) has been demonstrated to provide promising results, as the culture conditions may induce strong dependence on cytokines (70).

Naïve rather than central memory $\mathrm{T}$ cells give rise to an effector progeny with improved antitumor immunity following ACT (71). Effector cells derived from naïve T cells lose the expression of the central memory cell marker L-selectin more rapidly compared with those derived from central memory T cells, but do not acquire the expression of killer cell lectin-like receptor $\mathrm{G} 1$, which is a marker for terminal differentiation and replicative senescence (71). Thus, naïve-derived cells exhibit high proliferation and cytokine production following ACT (71). These results suggest that superior efficacy of ACT is obtained by insertion of genes that confer antitumor specificity into naïve $\mathrm{T}$ cells compared with central memory T cells (71).

The terminal differentiation status of transferred $\mathrm{T}$ cells and their low-affinity binding to tumor-associated antigens (TAAs) limit the effectiveness of patient-derived tumor-specific T cell ACT (72). TAAs are expressed in healthy tissues a low level (72). Transgenic TCRs or CARs recognize TAAs with high affinity and without MHC restriction, resulting in cytotoxic $\mathrm{T}$ cell activity against the tumor (72). However, a high risk of targeting healthy self-tissues occurs when central tolerance is overlooked. In order to achieve the greatest efficiency on tumors with the lowest risk of off-target and side effects, the choice of the TAA and of the TCR affinity is crucial (72).

Following transplantation into patients, infused $\mathrm{T}$ cells become functionally fatigued, and consequently their efficiency decreases (70). $\mathrm{CD}^{+} \mathrm{T}$ cells lose their antitumor efficacy as they produce IFN- $\gamma$, which activates the innate and adaptive immune response (73). This limitation may be resolved by the adoptive transfer of tumor antigen-specific stem cell memory T (TSCM) cells (73). TSCM cells are similar to naïve $\mathrm{T}$ cells but are also highly proliferative, exhibit a long lifespan and produce numerous effector $\mathrm{T}$ cells following antigen stimulation (73).

$\mathrm{T}$ cell-T cell interactions enhance the function of $\mathrm{T}$ cells within hours of molecular (antigen) stimulation (70). Enhanced cell motility is a short-time consequence of molecular stimulation, leading to aggregation and further activation (70). Functional activation of $\mathrm{T}$ cells is halted in the absence of $\mathrm{T}$ cell-T cell interactions even when continuous molecular stimulation is performed (70). Cryopreservation of the cellular product to perform lot release testing studies, followed by direct reinfusion to patients after conditioning chemotherapy is standard practice of CAR or TCR T cell therapy (70). An intermediate step of short-term ex vivo culture with molecular stimulation to induce $\mathrm{T}$ cell-T cell interactions may be favorable and result in more functional cells reinfused to the patients (70).

ACT in combination therapy. Compared with other immunotherapies, ACT has certain advantages, including $\mathrm{T}$ cell populations having optimal recognition of autologous tumor antigens that can be preferentially isolated ex vivo for therapy (74). These selected $\mathrm{T}$ cells can be expanded to large numbers under in vitro conditions that overcome tolerizing factors within the tumor microenvironment. In addition, regulatory and immunosuppressive factors can be eliminated by conditioning the host prior to cell transfer.

Since single-agent monotherapies are continuously proving futile, combination therapies utilizing two or more types of ACT or combinations of ACT and cell-based therapies have exhibited promising potential in the treatment of cancer such as melanoma (74). Traditional melanoma treatment includes the use of the chemotherapeutic agent dacarzabine, which exhibits a modest patient response of $10-20 \%$ with a complete response rate $<5 \%$ (74). Our previous studies have investigated the use of anthrax lethal toxin in murine models as a potential therapeutic agent for this disease and elaborated on the cellular mechanisms involved in the inhibition of Tregs (75).

In combination therapy, the use of TIL with high-dose IL2 generated a clinical response rate of 55\%, in which $\mathrm{T}$ cell-mediated tumor regression was observed (76). Additionally, $\mathrm{T}$ cell-based therapies that involve the co-delivery of cytokines such as IL-12, IFN- $\alpha$, IFN- $\gamma$ and TNF- $\alpha$ have enhanced the patient response (77). Other types of cancer such as glioblastoma multiforme (GBM) have been reported to respond to similar therapies. For example, our previous studies investigated the use of metformin, a biguanide agent used to treat type 2 diabetes mellitus, as well as human recombinant arginase I (Co)-PEG5000 [HuArgI (CO)-PRG5000] for the treatment of GBM $(78,79)$. In the context of immunotherapy, CAR T cell-based approaches in 
combination with radiotherapy exert synergistic efficacy in GBM (77).

\section{Cancer treatments involving ACT}

Epstein-Barr virus (EBV). EBV-induced lymphoma can be effectively treated with ACT therapy that restores anti-EBV immunity using viral-antigen-specific T cells (80). Repetitive in vitro stimulation of peripheral blood lymphocytes (PBLs) with EBV-B lymphoblastic cell lines has been used to generate lymphocyte cultures highly enriched for EBV-antigen-specific $\mathrm{T}$ cells that are suitable for ACT therapy and inhibit EBV-induced lymphoproliferation (80).

Non-viral antigen-expressing tumors. ACT therapies exhibit limited success in treating tumors that do not express viral antigens due to the difficulty in generating tumor-antigen-specific cells (80). One review that surveyed clinical trials involving non-specific activated lymphocytes or non-specific PBLs activated in vitro with anti-CD3 reported a low response rate for this therapy, suggesting the necessity of using tumor antigen-specific lymphocytes in ACT (80).

Limitations. Tumor recurrence is observed when cytotoxic $\mathrm{T}$ cell responses are inhibited by a subset of TGF $\beta$-responsive squamous cell carcinoma stem cells which evade immunotherapy via the expression of CD80, a co-stimulatory molecule involved in T-cell activation and the activity of normal and malignant B cells (81). Tumor-initiating stem cells (tSCs) possess self-renewal and differentiation capacities (81). These cells fuel and sustain tumor growth by overcoming the immune surveillance barrier (81). The ability of a regressed tumor to regrow implies that at least a number of tSCs acquire the ability to resist the enhanced antitumor immunity (81). One hypothesis is that $\mathrm{tSCs}$ exhibit limited antigen presentation and are therefore undetectable by the immune system (73). Alternatively, tSCs may be able to avoid immune attacks due to their antigen-editing, independent molecular features (82). These tSCs may become invasive in response to enriched TFG $\beta$ around the vessels; they are also more tumorigenic than tSCs distant from blood vessels, which do not receive a TGF $\beta$ stimulus (82). TGF $\beta$-responding tSCs survive chemotherapy and induce tumor relapse (83).

An effective mouse ACT model was established in a previous study, in which skin squamous cell carcinoma (SCC) tSCs were tracked, and their susceptibility was directly determined and compared with antigen-specific antitumor immune responses (81). The results demonstrated that TGF $\beta$-responding tSCs exhibited resistance to cytotoxic $\mathrm{T}$ cell responses and were responsible for tumor recurrence following ACT therapy (81). In addition, the aforementioned study demonstrated that within the tumor, these stem cells expressed the immune cell ligand CD80, the silencing of which diminished their resistance to immune surveillance and weakened tumor relapse (81).

Side effects of ACT. ACT is an effective cancer treatment, but it also has severe side effects. The variation and severity of these side effects vary depending on the patient health prior to treatment, the type and stage of cancer, as well as the type of T-cell transfer being used (84). The toxicity is observed as a result of direct T-cell attacks on normal tissues, i.e., autoimmunity (85). However, a number of normal tissues tolerate a certain degree of autoimmunity, and effective targeting of the antigens by these cells is still possible (85).

In CAR T-cell therapy, cytokine release syndrome is a side effect defined by the release of large amounts of cytokines into the blood, which ultimately leads to fever, chills, difficulty breathing, nausea, tachycardia, fatigue and muscle pain (84). Treatment with the monoclonal antibody tocilizumab is used to control this side effect (86). In addition, allergic reactions to CAR T cells have been recorded in a number of patients; the symptoms of allergic reactions include fever, difficulty breathing and chills (86). Increased risk of infection is observed as a side effect of certain types of CAR T-cell therapy when treating leukemias and lymphomas (86). The increased risk of infection occurs due to the recognition by CAR T cells of CD19, which is expressed on the surface of B cells; the CAR T-cells destroy the CD19+ $\mathrm{B}$ cells, leading to a decreased ability to fight infections (86). Immunoglobulin therapy is used to treat this side effect by administering antibodies to help fight infections (86).

TIL therapy causes capillary leak syndrome that is characterized by the leak of fluid and proteins out of small blood vessels into the surrounding tissues, leading to severe low blood pressure, which may lead to multiple organ failure (84). Neurological side effects that affect the brain have also been observed, and the symptoms include headaches, altered consciousness, speech changes, seizures and confusion (86). In addition, severe rashes leading to vitiligo occur in certain patients (86). A number of patients experience uveitis with impaired vision and decreased hearing, possibly due to autoimmunity against pigmented cells in the stria vascularis of the inner ear (85). These toxicities respond well to topical corticosteroids (85). In addition, hepatotoxicity has been observed in certain patients with renal cancer, as well as severe diarrhea in patients with colorectal cancer (85).

\section{Cancer vaccines: Types and therapeutic combinations}

Various cancer therapies do not evoke long-lasting immune responses and instead treat the patient immediately, which leads to the need for improvement of this treatment so that it induces robust responses that also hinder recurrence. Cancer vaccines may resolve this issue. Cancer vaccines have an advantage of being able to use the entire immune system of the individual, leading to strong and durable responses (87). In addition, mixing vaccines with other types of treatments, such as ICIs therapy, chemotherapy or radiotherapy also aims to enhance the immune response and the potency of treatment (87). Cancer vaccines may be use used not only used for prophylactic purposes, but also to ensure that the immune recognition of tumor antigens occurs more readily (87). A notable characteristic that should be taken into consideration when developing cancer vaccines is the classification of antigens into shared tumor antigens, which are common between most tumors of a certain histological type, and neoantigens, which are antigens that are subjected to various mutations that render them distinct from normal cells (87). These neoantigens give rise to neoepitopes, which elicit specific immune cell responses against them (87). The presence of $\mathrm{T}$ cells in 
the tumor microenvironment is associated with tumor regression and survival, which indicates the immunogenicity of most cancers (87). There are various types of DNA vaccines, allowing physicians and researchers to manipulate certain criteria of the vaccine for an improved immune response. The majority of vaccines have minimal AEs and are easily endured by patients (88). Multiple factors must be taken into consideration when designing any vaccine, including the antigen picked, the adjuvant used and the delivery mode. The various types of cancer vaccines are summarized in Table II.

DNA vaccines. DNA vaccines are usually bacterial plasmids containing genes encoding tumor antigens coupled to CMV promoters (89). These vaccines aim to induce an innate immune response that augments the adaptive immune response towards the tumor presenting these antigens (89). Thus, DNA vaccines aim to boost the production of $\mathrm{T}$ cells such as $\mathrm{CD}^{+}$and $\mathrm{CD}^{+}$cells that specifically target the tumor (5). Another aim of DNA vaccines is breaking immune tolerance and inducing an immune memory, especially in the cases where a DNA vaccine is used to prime the $\mathrm{T}$ cells against the antigen to improve the benefits of other therapeutic techniques (1). In the case of DNA vaccines, the DNA sequence may be engineered to improve protein expression, for instance by replacing the leader sequence with other sequences and adding immunoglobulins as well as performing codon and RNA optimization (5). In addition, a novel technique that has emerged recently in DNA vaccines and provides hope for cancer vaccination is synthetic consensus vaccines that rely on generating consensus DNA sequences based on comparing the native sequences between various species; these synthetic consensus sequences are able to break immune tolerance due to the increased diversity compared with that of the native sequences $(5,90)$. DNA vaccines can also be used in combination with other therapies to overcome certain limitations. ICIs targeting PD1 and CTLA4 have been demonstrated to enhance the antitumor activity of a DNA vaccine against mastocytoma by boosting its antitumor immunity, leading to a $\leq 90 \%$ survival rate (91). A previous clinical study has also investigated the therapeutic effects of combining DNA vaccines with cytokines such as IL-2 and IFN- $\gamma$ (88). In addition, the use of DNA vaccines is supported by the fact that intrinsic unmethylated $\mathrm{CpG}$ islands in the bacterial plasmid function as an adjuvant, thus stimulating the immune response to the vaccine (92). To determine the most effective combination of treatments and DNA vaccines, assessment of the tumor microenvironment as well as cells involved in the immunosuppressive behavior in that niche should be performed (93).

The mode of delivery should be taken into consideration when discussing the cellular mechanisms of DNA vaccines. DNA vaccines can be delivered through a variety of different routes including intramuscular, subcutaneous, mucosal or transdermal delivery (94). In addition, it is important to ensure that the plasmid transfects the cells, for which electroporation may be used (94). Furthermore, when the vaccine infects the cell, the plasmid is replicated in the cell, which is driven by the eukaryotic CMV promoter to produce that target antigens; following production of the antigens, they are then expressed in MHC class I and II, which are recognized by various immune cells and are capable of producing humoral and cellular immune responses (5).

The advantages of using DNA vaccines include their low cost, ability to elicit antigen-specific immune responses, easy sequence alteration, large-scale production and storage (93). In addition, DNA vaccines are not infectious and do not cause diseases or elicit immune responses in individuals of a specific MHC class (93). Therefore, in contrast to personalized vaccines, DNA vaccines may be considered versatile (93). Finally, as these antigens are expressed in the cells, they undergo post-translational modifications that form proteins similar to the host proteins, which ensures appropriate immune presentation (94).

On the other hand, certain disadvantages associated with DNA vaccines have been reported. DNA vaccines are negatively charged due to their DNA base and have a low molecular weight, which may cause difficulty in cellular uptake and poor antigenic production, leading to poor immune responses (92). Additionally, challenges occur in selecting the appropriate tumor antigen and combating the problems of poor immunogenicity and immunosuppressive microenvironments, which may lead to weak results in this field (95).

The only DNA cancer vaccine that has reached a phase III clinical trial is VGX-3100, which is a DNA vaccine targeting precancerous lesions that may progress to cervical cancer, termed CIN2/3 (96). This vaccine appears to elicit durable responses, but has not yet been approved by the FDA (96). In addition, DNA vaccines have been studied for breast, prostate, cervical, ovarian and pancreatic cancer, glioblastoma, melanoma, renal cell and urothelial carcinomas, but no significant progress has been reported beyond phase II clinical trials or even preclinical animal models (97).

Peptide vaccines. Peptide vaccines consist of nongenetic components of the disease to be treated, such a tumor or an infectious agent, in order to elicit an immune response (98). Peptide vaccines do not unnecessarily overload the immune system, as only the epitope of interest is delivered to the immune system of the individual (99). These vaccines are also cheap and can be easily produced (99). However, they usually fail to elicit an immune response due to the presence of immunosuppressive molecules in the tumor microenvironment (100), and the safety of these vaccines when combined with adjuvants remains unclear; thus, the safety of usage of adjuvants should be assessed and eliminated in order to ensure the efficacy of peptide vaccines (99). Therefore, current research aims to improve peptide vaccines. For example, peptide vaccines may be potentiated by combination with other molecules, such as avasimibe, a molecule that aids in cholesterol metabolism and increases the potentiation of a Kras vaccine targeting lung tumors (101), indomecathin, which reduces the rate of proliferation in tumor cells and increases the apoptotic rate when used in conjunction with a MUC1 peptide vaccine (100), or by adding adjuvants as the antigens by themselves provide low immunogenicity and MHC restriction (102). Future research is required to enhance the immune response in other manners such as utilizing protein nanoparticles that surround the peptides, which is an approach that offers numerous merits including a symmetrical structure, biodegradability and an appropriate size for the delivery of vaccines (103). 
One FDA-approved vaccine that is not strictly a peptide vaccine, but may be considered to be one, is IMLYGIC or T-VEC, which is a modified herpes simplex virus 1 that replicates in the lesions of patients with recurrent melanoma, causing cell lysis and death (104). The reason why it may be considered a peptide vaccine is that this virus is engineered to express the granulocyte-macrophage colony-stimulating factor, which promotes the antitumor response and priming of T cells (104).

DC vaccines. DCs were first described by Robert Steinman in 1973 due to their unique shape and high MHC expression (105). DC vaccines are vaccines produced by harvesting patient DCs and transfecting them with the tumor antigen ex vivo; these cells are then re-introduced into the patient's body which can usually occur via many routes including intradermal, intravenous, intranodal and intralymphatic routes, to destroy the tumor cells that they readily recognize (106). DCs possess an ability to modulate adaptive immune responses, which renders them as potent stimulatory tools for memory and immune cells $(91,106)$. In addition, DCs stimulate naïve T cells (106). However, DCs are low in number in the peripheral blood and tissues, and thus, their population needs to be enhanced in vivo or ex vivo prior to vaccine administration (107). The advantages of DC vaccines include their personalized nature, the feasibility of producing an immune response since dendritic cells are major players in the activation of adaptive responses, their ability to specify the response towards one antigen or a group of antigens and the relatively safety in individuals as they do not cause AEs (108). By contrast, DC-based vaccines, similar to other vaccines, face certain hurdles, such as tumor immunosuppression and the limited functions of monocyte-derived dendritic cells, which are the cells used to generate this type of vaccines (109). In addition, since they are personalized, DC vaccines tend to be expensive (109). As with other types of vaccines, DC vaccines suppress tumor growth and increase the number of $\mathrm{T}$ cells infiltrating the tumor microenvironment, which can be more efficient compared with other types of vaccines in certain cases, such as in murine lung carcinoma (LL2), the study was done in vitro and the DC vaccine was able to exhibit superior immunogenicity compared with an antigen-adjuvant vaccine (102). Furthermore, DC cancer vaccines may also be used with other treatments for enhanced results, including ICIs such as anti-PD-1 and adjuvants (110). Using a mathematical model, Lai and Friedman (111) have demonstrated a synergistic effect of the combination of a DC cancer vaccine and anti-PD1 in cancer therapy. In laboratory preparation of DC vaccines, observing and controlling culture conditions is crucial since DCs are highly sensitive to their environment (110). Particular care should be taken in identifying the molecules that allow efficient delivery of DC cells to the lymph nodes for maturation (110).

One example of an FDA-approved DC cancer vaccine is Sipuleucel-T or PROVENGE, which is used in the treatment of metastatic castration-resistant prostate cancer with metastasis beyond the prostate gland that cannot be treated by hormone therapy (112). DC vaccines for other types of cancer have not been approved; however, current efforts are aimed towards metastatic melanoma, breast and prostate cancer (113).
Whole-cell vaccines. Whole-cell cancer vaccines contain whole tumor cells that have been modified ex vivo (114). Despite the lack of strong results in cancer vaccination, whole-cell vaccines offer numerous advantages. One advantage is that whole-cell vaccines express both tumor-specific and tumor-associated antigens (114). Additionally, whole-cell vaccines elicit strong cellular as well as humoral immune responses (114). However, tumor cells possess immune evasion strategies, which must be considered when modifying tumor cells to achieve adequate immunogenicity (115). In addition, whole-cell vaccines have not elicited strong immune responses in clinical trials, possibly because advanced tumors build immune tolerance that hinders immune recognition (114). Whole-cell vaccines are also time consuming, laborious and costly due to the numerous procedures needed to acquire, maintain, manipulate and reintroduce tumor cells to the individual (108). Carbohydrate antigens in the context of whole-cell vaccines are also important as they are expressed on the surface of cells in the form glycoproteins, proteoglycans and glycolipids, and are necessary for various biological processes including aberrant processes implicated in carcinogenesis (116). Xia et al (116) have developed a glycol-antigen microarray to study antibody responses to carbohydrates induced by whole-cell vaccines and reported high IgG and IgM responses induced by the GVAX pancreatic cancer vaccine, indicating the importance of other types of antigens in addition to peptide antigens (116). In terms of combination therapy, one study by Chen et al (117) has reported that combining a whole-cell breast cancer vaccine with the standard chemotherapeutic alkylating agent cyclophosphamide increases the clinical benefits of this agent in treating Her $2^{+}$metastatic breast cancer.

Cancer vaccination has been a potent field of research for the treatment of cancer in the past 30 years (88). Cancer vaccines can be used in two different manners: A prophylactic application that aims to prevent disease or as vaccine-mediated postoperative immunotherapy for recurrent and metastatic tumors. One major challenge for cancer vaccines is the interpatient variability of cellular responses, which causes a robust immune response in certain individuals, but no response in others (88). Another challenge is that cancer vaccines by themselves may not be efficient and require prior priming or co-priming of the immune system using other substances that potentiate the vaccine $(101,102,118)$. In addition, limited knowledge is currently available on the intracellular processing and tracking in humans as opposed to animals due to ethical concerns (88). However, despite these drawbacks, cancer vaccines may have positive inclinations in the future, especially when combined with other types of treatment (88).

\section{Monoclonal antibodies in immunotherapy (IT)}

George Köhler and Cesar Milstein defined their attempt at circumventing the deficiencies of the prior methods that were considered permanent cultures of Myeloma cells that lacked 'a satisfactory source of monoclonal antibodies of predefined specificity' as capable of being 'valuable for medical use' (119). In order to benefit from the boundaries of antibody yield and lifespan, George Köhler and Cesar Milstein fused a myeloma cell line P3-X63-Ag8 with spleen cells from a mouse immunized with sheep red blood cells to generate hybridoma cells 


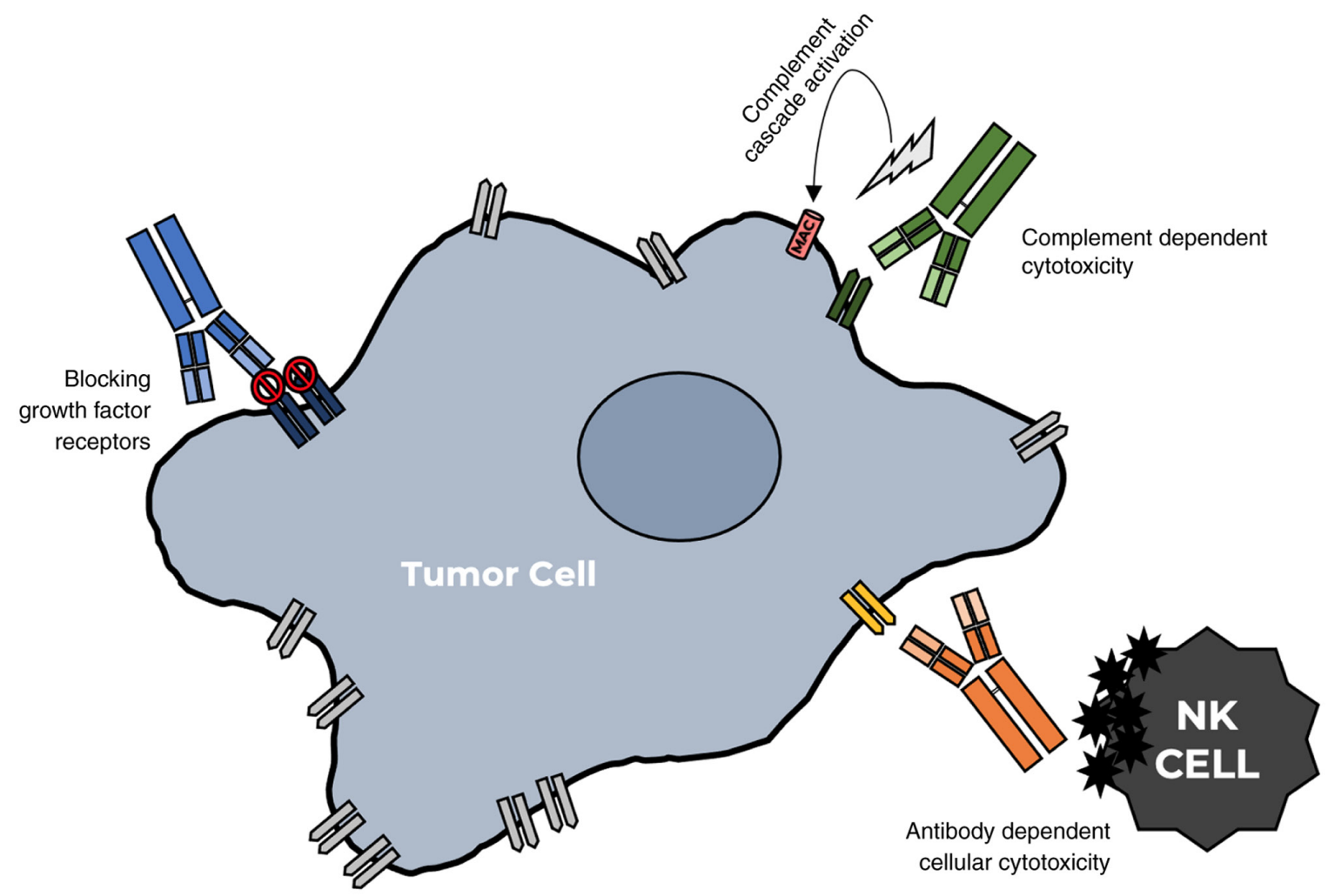

Figure 1. A diagram illustrating the immunological mechanisms of an mAb via activating antibody-dependenT cellular cytotoxicity, blocking growth factor receptors and activating complement-dependent cytotoxicity by complement activation via the membrane attack complex. Figure is based on information from Chung et al (120). MAC, membrane attack complex; NK, natural killer.

that release antibodies with homogeneous specificity towards one antigen: Monoclonal antibodies (mAbs) (119).

The antibody modes of action. Antibodies are proteins engineered to target an epitope present on cancer cells (when used for immunotherapeutic purposes) and are produced, collected and administered to a patient and they circulate throughout the body until they meet the aforementioned antigen. They recruit other immune system agents to eliminate the antigen via three main mechanisms: Activating antibody-dependenT cellular cytotoxicity (ADCC), blocking growth factor (GF) receptors, and activating complement-dependent cytotoxicity (CDC) by complement activation (Fig. 1) (120). Understanding the mechanisms by which mAbs work must precede their application to ensure efficacy.

For activating ADCC, a specifically designed $\mathrm{mAb}$ attaches to a previously specified antigen and allows NK cells to recognize and eliminate it by releasing cytotoxic agents, which kills the cell by apoptosis $(121,122)$. Targeting GF receptors is achieved by using several mAbs to competitively inhibit these receptors (123). For instance, targeting epidermal growth factor receptor blocks its use, causing the internalization and downregulation of the receptor (123). In CDC, a mAb binds to antigens on the targeT cell surface and triggers multiple pathways in the complement cascade, where complements (various soluble plasma proteins and membrane proteins) bind to the mAbs, induce an attack and lead to the lysis of the targeted cell (124).

Types of mAbs used in IT. There are three types of mAbs that are used in cancer treatment: Naked, conjugated and bi-specific. Naked mAbs are used without any drugs (125). For example, rituximab induces tumor cell death through the dependent and independent mechanisms centered on Fc (125). The dependent mechanism contains the aforementioned ADCC mechanism mediated by NK cells and macrophages, antibody-dependenT cellular phagocytosis mediated by macrophages and CDC (125). Apoptosis is directly induced by the independent $\mathrm{Fc}$ mechanisms by the binding of a mAb to its receptor or by its blocking of receptor-ligand interactions, as is the case with the HER2 receptor-mediated GF signaling on cancer cells (126). Conjugated mAbs are tools through which chemotherapeutic agents and radioactive molecules are led directly to targeted cells (125). The conjugation of mAbs with radioactive substances, such as iodine-131 or yttrium-90, generates cytotoxic molecules, such as monomethyl auristatin E or emtansine, improves efficacy compared with that of naked mAbs and generates antibody-drug conjugates (125). This facilitates the delivery of cytotoxic agents to tumor cells, increasing their efficiency (126). Bispecific (or bifunctional) $\mathrm{mAbs}$ are a type of mAbs in which two IgG chains of different specificity are amalgamated; they can be administered to effectively bind two different surface antigens, which eases the burden of the patient significantly by decreasing the frequency with which this procedure is administered (127).

$m A b s$ and combination therapy. mAb monotherapy has been successful in treating certain patients with cancer, but current studies are shifting towards combining $\mathrm{mAb}$ with other antitumor therapies for a more effective treatment: mAbs and ICIs $(128,129)$. The effect of the mAb cetuximab 
in treating head and neck squamous cell carcinoma appears to be enhanced when combined with inhibitors of the immune checkpoint PD-1/PD-1L such as anti-PD-1 antibodies and pembrolizumab (128). In addition, resistance to the monotherapy of the mAb trastuzumab in advanced HER $2^{+}$breast cancer may be overcome with the use of pembrolizumab (129).

In addition to immune checkpoint blockage, cytokine immunotherapy is also synergistic with monoclonal antibody therapy. An engineered PEGylated IL-2 is currently undergoing clinical trials in which it is combined with the $\mathrm{mAb}$ Nivolumab for the treatment of advanced solid tumors (130). PEGylated IL-2 has also exhibited potential therapeutic advantage when combined with the mAb Atezolizumab in treating NSCLC (131).

The downsides of $m A b s$ in IT. There are several side effects for $\mathrm{mAb}$ treatments against cancer. In one case, upon treating 496 patients with metastatic melanoma with anti-PD1 antibodies, 242 side effects were described in 138 patients, including skin, gastrointestinal and renal system side effects, and, in certain cases, rare side effects including diabetes mellitus and pancreatitis (23). In addition, in patients with melanoma treated with Nivolumab or pembrolizumab, side effects were observed in the respiratory tract, musculoskeletal system, nervous system, eyes, heart and blood (132).

The future of mAbs in IT. As far as the future of monoclonal antibodies is concerned, this technology may improve the current shortcomings in cancer therapeutics. mAbs possess specificity for certain conformations to ensure improved selectivity and fulfillment of therapeutic goals. However, the most prominent limitation currently is that the majority of mAbs are unable to recognize 3D configurations. Thus, 3D-recognizing antibodies may be valuable to offer an extra level of neutralization.

\section{Conclusions}

The present review of the various approaches of cancer immunotherapy aimed to comprehensively describe the modes of action and limitations of the current approaches to cancer treatment via immunotherapy. The use of cytokines in cancer immunotherapy is among the most promising approaches. This review focused on one of the most extensively studied cytokines, IL-2, and highlighted other promising cytokines reported in literature. Current research is focusing on using multiple cytokines together in therapy, combined therapies and fusion proteins that provide improved specificity and longer half-lives. ICIs have been reported to have a positive effect on the treatment of various types of cancer, especially if applied in combined therapy. These promising findings may revolutionize immunological cancer treatments. ACT is an effective type of immunotherapy in which $\mathrm{T}$ cells obtained from the patient or donors are administered to patients to help fight diseases such as cancer. The present review discussed several types of ACT therapy in addition to the factors that determine the efficacy of this treatment. In addition, the advantages and side effects of ACT therapy were described. Although several limitations hinder the efficiency of ACT, research and clinical trials are focusing on the development and future of this technique. In the cancer vaccines section, the types of therapeutic cancer vaccines were introduced, with an emphasis on their advantages and disadvantages as well as their function in combination therapy. The review on cancer vaccines also included specific examples of approved vaccines and those undergoing clinical trials. Finally, the current review discussed mAbs, their modes of action, advantages and limitations of using them as well as their future and applications in combination therapy. In addition, specific downsides of immunotherapy were discussed in this review. Notably, the information presented here does not constitute the entirety of the knowledge on this topic; the present review highlights basic knowledge pertaining to cytokines, ICIs, ACT, cancer vaccines and mAbs in cancer immunotherapy. Finally, this review does not seek to give the impression that immunotherapy is the only method of treating cancer, as there are other methods used in a complementary manner to immunotherapy or by themselves to treat cancer.

\section{Acknowledgements}

The authors would like to thank Dr Ralph Abi-Habib (Lebanese American University, Beirut, Lebanon) for his critical reading of the manuscript.

\section{Funding}

This work was supported by the Department of Natural Sciences at the School of Arts and Science at the Lebanese American University.

\section{Availability of data and materials}

Not applicable.

\section{Authors' contributions}

MH, ZO, RR, FW, AZ and MF all wrote different sections of the manuscript. EAK and MES wrote the final draft and edited it for important intellectual content. Data authentication is not applicable. All the authors have read and approved the final manuscript.

\section{Ethics approval and consent to participate}

Not applicable.

\section{Patient consent for publication}

Not applicable.

\section{Competing interests}

The authors declare that they have no competing interests.

\section{References}

1. Koo SL, Wang WW and Toh HC: Cancer Immunotherapy-The target is precisely on the cancer and also not. Ann Acad Med Singap 47: 381-387, 2018.

2. Meng J, Zhou Y, Lu X, Bian Z, Chen Y, Zhou J, Zhang L, Hao Z, Zhang $M$ and Liang $C$ : Immune response drives outcomes in prostate cancer: Implications for immunotherapy. Mol Oncol 15: 1358-1375, 2021 
3. Balachandran VP, Beatty GL and Dougan SK: Broadening the impact of immunotherapy to pancreatic cancer: Challenges and opportunities. Gastroenterology 156: 2056-2072, 2019.

4. Parkin $\mathrm{J}$ and Cohen B: An overview of the immune system. Lancet 357: 1777-1789, 2001

5. Perales-Puchalt A, Wojtak K, Duperret EK, Yang X, Slager AM, Yan J, Muthumani K, Montaner LJ and Weiner DB: Engineered DNA vaccination against follicle-stimulating hormone receptor delays ovarian cancer progression in animal models. Mol Ther 27: 314-325, 2019.

6. Pedersen M, Westergaard MCW, Milne K, Nielsen M, Borch TH, Poulsen LG, Hendel HW, Kennedy M, Briggs G, Ledoux S, et al: Adoptive cell therapy with tumor-infiltrating lymphocytes in patients with metastatic ovarian cancer: A pilot study. OncoImmunology 7: e1502905, 2018.

7. Mitchell DM, Ravkov EV and Williams MA: Distinct roles for IL-2 and IL-15 in the differentiation and survival of CD8+ effector and memory T cells. J Immunol 184: 6719-6730, 2010.

8. Jaeckel E, Kretschmer K, Apostolou I and von Boehmer H: Instruction of Treg commitment in peripheral $\mathrm{T}$ cells is suited to reverse autoimmunity. Semin Immunol 18: 89-92, 2006.

9. Brisslert M, Bokarewa M, Larsson P, Wing K, Collins LV and Tarkowski A: Phenotypic and functional characterization of human CD25+ B cells. Immunology 117: 548-557, 2006.

10. Kim HP, Imbert J and Leonard WJ: Both integrated and differential regulation of components of the IL-2/IL-2 receptor system. Cytokine Growth Factor Rev 17: 349-366, 2006.

11. Smith FO, Downey SG, Klapper JA, Yang JC, Sherry RM, Royal RE, Kammula US, Hughes MS, Restifo NP, Levy CL, et al: Treatment of metastatic melanoma using interleukin-2 alone or in conjunction with vaccines. Clin Cancer Res 14: 5610-5618, 2008

12. Lopes JE, Fisher JL, Flick HL, Wang C, Sun L, Ernstoff MS Alvarez JC and Losey HC: ALKS 4230: A novel engineered IL-2 fusion protein with an improved cellular selectivity profile for cancer immunotherapy. J Immunother Cancer 8: e000673, 2020 .

13. Attridge K, Wang CJ, Wardzinski L, Kenefeck R, Chamberlain JL, Manzotti C, Kopf M and Walker LS: IL-21 inhibits T cell IL-2 production and impairs Treg homeostasis. Blood 119: 4656-4664, 2012.

14. Zimmerman RJ, Aukerman SL, Katre NV, Winkelhake JL and Young JD: Schedule dependency of the antitumor activity and toxicity of polyethylene glycol-modified interleukin 2 in murine tumor models. Cancer Res 49: 6521-6528, 1989.

15. Rosenberg SA: IL-2: The first effective immunotherapy for human cancer. J Immunol 192: 5451-5458., 2014.

16. Grimm EA, Mazumder A, Zhang HZ and Rosenberg SA Lymphokine-activated killer cell phenomenon. Lysis of natural killer-resistant fresh solid tumor cells by interleukin 2-activated autologous human peripheral blood lymphocytes. J Exp Med 155: 1823-1841, 1982

17. Dudley ME, Wunderlich JR, Yang JC, Sherry RM, Topalian SL, Restifo NP, Royal RE, Kammula U, White DE, Mavroukakis SA, et al: Adoptive cell transfer therapy following non-myeloablative but lymphodepleting chemotherapy for the treatment of patients with refractory metastatic melanoma. J Clin Oncol 23: 2346-2357, 2005 .

18. Krieg C, Létourneau S, Pantaleo G and Boyman O: Improved IL-2 immunotherapy by selective stimulation of IL-2 receptors on lymphocytes and endothelial cells. Proc Natl Acad Sci USA 107: 11906-11911, 2010

19. Nasreddine G, El-Sibai M and Abi-Habib RJ: Cytotoxicity of [HuArgI (co)-PEG5000]-induced arginine deprivation to ovarian cancer cells is autophagy dependent. Invest New Drugs 38: 10-19, 2020.

20. Ingersoll SB, Ahmad S, McGann HC, Banks RK, Stavitzski NM, Srivastava M, Ali G, Finkler NJ, Edwards JR and Holloway RW: Cellular therapy in combination with cytokines improves survival in a xenograft mouse model of ovarian cancer. Mol Cell Biochem 407: 281-287, 2015

21. Ingersoll SB, Patel S, Caballero L, Ahmad S, Edwards D, Holloway RW and Edwards JR: Synergistic cytotoxicity of interferonalpha-2b and interleukin-2 in combination with PBMC against ovarian cancer: Development of an experimental model for cellular therapy. Gynecol Oncol 112: 192-198, 2009

22. Di Scala M, Gil-Fariña I, Olagüe C, Vales A, Sobrevals L, Fortes P, Corbacho D and González-Aseguinolaza G: Identification of IFN- $\gamma$-producing T cells as the main mediators of the side effects associated to mouse interleukin-15 sustained exposure. Oncotarget 7: 49008-49026, 2016.
23. Miller JS, Morishima C, McNeel DG, Patel MR, Kohrt HEK, Thompson JA, Sondel PM, Wakelee HA, Disis ML, Kaiser JC, et al: A First-in-Human Phase I Study of subcutaneous outpatient recombinant human IL15 (rhIL15) in adults with advanced solid tumors. Clin Cancer Res 24: 1525-1535, 2018.

24. Conlon KC, Lugli E, Welles HC, Rosenberg SA, Fojo AT, Morris JC, Fleisher TA, Dubois SP, Perera LP, Stewart DM, et al: Redistribution, hyperproliferation, activation of natural killer cells and CD8 T cells, and cytokine production during First-in-Human clinical trial of recombinant human Interleukin-15 in patients with cancer. J Clin Oncol 33: 74-82, 2015.

25. Rubinstein MP, Kovar M, Purton JF, Cho JH, Boyman O, Surh CD and Sprent J: Converting IL-15 to a superagonist by binding to soluble IL-15R \{alpha\}. Proc Natl Acad Sci USA 103: 9166-9171, 2006

26. Ochoa MC, Fioravanti J, Rodriguez I, Hervas-Stubbs S, Azpilikueta A, Mazzolini G, Gúrpide A, Prieto J, Pardo J, Berraondo P and Melero I: Antitumor immunotherapeutic and toxic properties of an HDL-Conjugated Chimeric IL-15 fusion protein. Cancer Res 73: 139-149, 2013

27. Mortier E, Quéméner A, Vusio P, Lorenzen I, Boublik Y, Grötzinger J,Plet A and Jacques Y: Soluble interleukin-15 receptor alpha (IL-15R alpha)-sushi as a selective and potent agonist of IL-15 action through IL-15R beta/gamma. Hyperagonist IL-15 x IL-15R alpha fusion proteins. J Biol Chem 281: 1612-1619, 2006.

28. Ochoa MC, Minute L, López A, Pérez-Ruiz E, Gomar C, Vasquez M, Inoges S, Etxeberria I, Rodriguez I, Garasa S, et al: Enhancement of antibody-dependenT cellular cytotoxicity of cetuximab by a chimeric protein encompassing interleukin-15. Oncoimmunology 7: e1393597, 2017.

29. Rhode PR, Egan JO, Xu W, Hong H, Webb GM, Chen X, Liu B, Zhu X, Wen J, You L, et al: Comparison of the superagonist complex, ALT-803, to IL15 as cancer immunotherapeutics in animal models. Cancer Immunol Res 4: 49-60, 2016.

30. Romee R, Cooley S, Berrien-Elliott MM, Westervelt $P$, Verneris MR, Wagner JE, Weisdorf DJ, Blazar BR, Ustun C, DeFor TE, et al: First-in-human phase 1 clinical study of the IL-15 superagonist complex ALT-803 to treat relapse after transplantation. Blood 131: 2515-2527, 2018.

31. Rosser CJ, Nix L, Ferguson L, Hernandez L and Wong HC: Phase Ib trial of ALT-803, an IL-15 superagonist, plus BCG for the treatment of BCG-naïve patients with non-muscle-invasive bladder cancer. J Clin Oncol 36 (Suppl 6): 510, 2021.

32. Timmerman JM, Byrd JC, Andorsky DJ, Yamada RE, Kramer J, Muthusamy N, Hunder N and Pagel JM: A phase I dose-finding trial of recombinant interleukin-21 and rituximab in relapsed and refractory low grade B-cell lymphoproliferative disorders. Clin Cancer Res 18: 5752-5760, 2012.

33. Fioravanti J, Di Lucia P, Magini D, Moalli F, Boni C, Benechet AP, Fumagalli V, Inverso D, Vecchi A, Fiocchi A, et al: Effector CD8+ T cell-derived interleukin-10 enhances acute liver immunopathology. J Hepatol 67: 543-548, 2017.

34. Koski A, Kangasniemi L, Escutenaire S, Pesonen S, Cerullo V, Diaconu I, Nokisalmi P, Raki M, Rajecki M, Guse K, et al: Treatment of cancer patients with a serotype $5 / 3$ chimeric oncolytic adenovirus expressing GMCSF. Mol Ther 18: 1874-1884, 2010.

35. Spaapen RM, Leung MY, Fuertes MB, Kline JP, Zhang L, Zheng Y, Fu YX, Luo X, Cohen KS and Gajewski TF: Therapeutic activity of High-Dose Intratumoral IFN- $\beta$ requires direct effect on the tumor vasculature. J Immunol 193: 4254-4260, 2014.

36. Herndon TM, Demko SG, Jiang X, He K, Gootenberg JE, Cohen MH, Keegan P and Pazdur R: U.S. Food and Drug Administration Approval: Peginterferon-alfa-2b for the adjuvant treatment of patients with melanoma. Oncologist 17: 1323-1328, 2012.

37. Bellobuono A, Mondazzi L, Tempini S, Silini E, Vicari F and Idéo G. Ribavirin and interferon-alpha combination therapy vs interferon-alpha alone in the retreatment of chronic hepatitis $\mathrm{C}$ : A randomized clinical trial. J Viral Hepat 4: 185-191, 1997.

38. Gogas H, Ioannovich J, Dafni U, Stavropoulou-Giokas C, Frangia K, Tsoutsos D, Panagiotou P, Polyzos A, Papadopoulos O, Stratigos A, et al: Prognostic significance of autoimmunity during treatment of melanoma with interferon. N Engl J Med 354: 709-718, 2006

39. Fioravanti J, González I, Medina-Echeverz J, Larrea E, Ardaiz N, González-Aseguinolaza G, Prieto J and Berraondo P: Anchoring interferon alpha to apolipoprotein A-I reduces hematological toxicity while enhancing immunostimulatory properties. Hepatology 53: 1864-1873, 2011. 
40. Cauwels A, Van Lint S, Paul F, Garcin G, De Koker S, Van Parys A, Wueest T, Gerlo S, Van der Heyden J, Bordat Y, et al: Delivering Type I interferon to dendritic cells empowers tumor eradication and immune combination treatments. Cancer Res 78: 463-474, 2018.

41. Palladino MA, Bahjat FR, Theodorakis EA and Moldawer LL: Anti-TNF-alpha therapies: The next generation. Nat Rev Drug Discov 2: 736-746, 2003

42. Creaven PJ, Plager JE, Dupere S, Huben RP, Takita H, Mittelman A and Proefrock A: Phase I clinical trial of recombinant human tumor necrosis factor. Cancer Chemother Pharmacol 20: 137-144, 1987.

43. Zheng L, Fisher G, Miller RE, Peschon J, Lynch DH and Lenardo MJ: Induction of apoptosis in mature T cells by tumour necrosis factor. Nature 377: 348-351, 1995.

44. Kahn JO, Kaplan LD, Volberding PA, Ziegler JL, Crowe S, Saks SR and Abrams DI: Intralesional recombinant tumo necrosis factor-alpha for AIDS-associated Kaposi's sarcoma: A randomized, double-blind trial. J Acquir Immune Defic Syndr 2: 217-223, 1989

45. Manusama ER, Nooijen PT, Stavast J, Durante NM, Marquet RL and Eggermont AM: Synergistic antitumour effect of recombinant human tumour necrosis factor alpha with melphalan in isolated limb perfusion in the rat. Br J Surg 83: 551-555, 1996.

46. Lejeune FJ, Liénard D, Matter M and Rüiegg C: Efficiency of recombinant human TNF in human cancer therapy. Cancer Immun 6: 6, 2006

47. van Horssen R, Ten Hagen TL and Eggermont AM: TNF-alpha in cancer treatment: Molecular insights, antitumor effects, and clinical utility. Oncologist 11: 397-408, 2006

48. Herzberg B, Campo MJ and Gainor JF: Immune checkpoint inhibitors in non-small cell lung cancer. Oncologist 22: 81-88, 2017.

49. Delgobo M and Frantz S: Heart failure in cancer: Role of checkpoint inhibitors. J Thorac Dis 10 (Suppl 35): S4323-S4334, 2018

50. Wolchok JD, Chiarion-Sileni V, Gonzalez R, Rutkowski P, Grob JJ, Cowey CL, Lao CD, Wagstaff J, Schadendorf D, Ferrucci PF, et al: Overall survival with combined nivolumab and ipilimumab in advanced melanoma. N Engl J Med 377: $1345-1356,2017$

51. Kamath SD and Kumthekar PU: Immune checkpoint inhibitors for the treatment of central nervous system (CNS) metastatic disease. Front Oncol 8: 414, 2018.

52. Heinzerling L, Ott PA, Hodi FS, Husain AN, Tajmir-Riahi A, Tawbi H, Pauschinger M, Gajewski TF, Lipson EJ and Luke JJ: Cardiotoxicity associated with CTLA4 and PD1 blocking immunotherapy. J Immunother Cancer 4: 50, 2016.

53. Sznol M, Postow MA, Davies MJ, Pavlick AC, Plimack ER, Shaheen M, Veloski C and Robert C: Endocrine-related adverse events associated with immune checkpoint blockade and expert insights on their management. Cancer Treat Rev 58: 70-76, 2017.

54. Hassel JC, Heinzerling L, Aberle J, Bähr O, Eigentler TK, Grimm MO, Grünwald V, Leipe J, Reinmuth $\mathrm{N}$, Tietze JK, et al: Combined immune checkpoint blockade (anti-PD-1/anti-CTLA-4): Evaluation and management of adverse drug reactions. Cancer Treat Rev 57: 36-49, 2017

55. Simonaggio A, Michot JM, Voisin AL, Le Pavec J, Collins M, Lallart A, Cengizalp G, Vozy A, Laparra A, Varga A, et al: Evaluation of readministration of immune checkpoint inhibitors after immune-related adverse events in patients with cancer. JAMA Oncol 5: 1310-1317, 2019.

56. Santini FC, Rizvi H, Plodkowski AJ, Ni A, Lacouture ME, Gambarin-Gelwan M, Wilkins O, Panora E, Halpenny DF, Long NM, et al: Safety and efficacy of re-treating with immunotherapy after immune-related adverse events in patients with NSCLC. Cancer Immunol Res 6: 1093-1099, 2018

57. Kluger HM, Zito CR, Turcu G, Baine MK, Zhang H, Adeniran A, Sznol M, Rimm DL, Kluger Y, Chen L, et al: PD-L1 studies across tumor types, its differential expression and predictive value in patients treated with immune checkpoint inhibitors. Clin Cancer Res 23: 4270-4279, 2017.

58. Fan J, Shang D, Han B, Song J, Chen H and Yang JM: Adoptive cell transfer: Is it a promising immunotherapy for colorectal cancer? Theranostics 8: 5784-5800, 2018

59. Wrangle J, Paulos CM, Smith TW, Nishimura MI and Rubinstein MP: Inducible enhancement of T cell function and anti-tumor activity after adoptive transfer. Mol Ther 25: 1995-1996, 2017

60. Rohaan MW, Wilgenhof S and Haanen JBAG: Adoptive cellular therapies: The current landscape. Virchows Arch 474: 449-461, 2019.
61. Mitchison NA: Studies on the immunological response to foreign tumor transplants in the mouse. I. The role of lymph node cells in conferring immunity by adoptive transfer. J Exp Med 102: $157-177,1955$.

62. Fefer A: Immunotherapy and chemotherapy of Moloney sarcoma virus-induced tumors in mice. Cancer Res 29: 2177-2183, 1969.

63. Rosenberg SA and Terry WD: Passive immunotherapy of cancer in animals and man. Adv Cancer Res 25: 323-388, 1977.

64. Kono K, Ichihara F, Iizuka H, Sekikawa T and Matsumoto Y: Expression of signal transducing T-cell receptor zeta molecules after adoptive immunotherapy in patients with gastric and colon cancer. Int J Cancer 78: 301-305, 1998.

65. Lu TL, Pugach O, Somerville R, Rosenberg SA, Kochenderfer JN, Better M and Feldman SA: A Rapid cell expansion process for production of engineered autologous CAR-T cell therapies. Hum Gene Ther Methods 27: 209-218, 2016.

66. Xiao L, Cen D, Gan H, Sun Y, Huang N, Xiong H, Jin Q, Su L, Liu X, Wang K, et al: Adoptive transfer of NKG2D CAR mRNA-Engineered natural killer cells in colorectal cancer patients. Mol Ther 27: 1114-1125, 2019.

67. Vivier E, Raulet DH, Moretta A, Caligiuri MA, Zitvogel L, Lanier LL, Yokoyama WM and Ugolini S: Innate or adaptive immunity? The example of natural killer cells. Science 331: 44-49, 2011

68. Morvan MG and Lanier LL: NK cells and cancer: You can teach innate cells new tricks. Nat Rev Cancer 16: 7-19, 2016.

69. Basar R, Daher M and Rezvani K: Next-generation cell therapies: The emerging role of CAR-NK cells. Blood Adv 4: 5868-5876, 2020.

70. Zhou J, Bethune MT, Malkova N, Sutherland AM, Comin-Anduix B, Su Y, Baltimore D, Ribas A and Heath JR: A kinetic investigation of interacting, stimulated $\mathrm{T}$ cells identifies conditions for rapid functional enhancement, minimal phenotype differentiation, and improved adoptive cell transfer tumor eradication. PLoS One 13: e0191634, 2018.

71. Hinrichs CS, Borman ZA, Cassard L, Gattinoni L, Spolski R, Yu Z, Sanchez-Perez L, Muranski P, Kern SJ, Logun C, et al: Adoptively transferred effector cells derived from naive rather than central memory CD8+ T cells mediate superior antitumor immunity. Proc Natl Acad Sci USA 106: 17469-17474, 2009.

72. De Sanctis F, Trovato R and Ugel S: Anti-telomerase T cells adoptive transfer. Aging (Albany NY) 9: 2239-2240, 2017.

73. Kondo T, Imura Y, Chikuma S, Hibino S, Omata-Mise S, Ando M, Akanuma T, Iizuka M, Sakai R, Morita R and Yoshimura A: Generation and application of human induced-stem cell memory T cells for adoptive immunotherapy. Cancer Sci 109: 2130-2140, 2018.

74. Foley KC, Nishimura MI and Moore TV: Combination immunotherapies implementing adoptive T-cell transfer for advanced-stage melanoma. Melanoma Res 28: 171-184, 2018.

75. Abi-Habib RJ, Singh R, Leppla SH, Greene JJ, Ding Y, Berghuis B, Duesbery NS and Frankel AE: Systemic anthrax lethal toxin therapy produces regressions of subcutaneous human melanoma tumors in athymic nude mice. Clin Cancer Res 12: 7437-7443, 2006

76. Kong LY, Abou-Ghazal MK, Wei J, Chakraborty A, Sun W, Qiao W, Fuller GN, Fokt I, Grimm EA, Schmittling RJ, et al: A novel inhibitor of signal transducers and activators of transcription 3 activation is efficacious against established central nervous system melanoma and inhibits regulatory T cells. Clin Cancer Res 14: 5759-5768, 2008.

77. Weiss T, Weller M, Guckenberger M, Sentman CL and Roth P: NKG2D-Based CAR T cells and radiotherapy exert synergistic efficacy in glioblastoma. Cancer Res 78: 1031-1043, 2018.

78. Al Hassan M, Fakhoury I, El Masri Z, Ghazale N, Dennaoui R, El Atat O, Kanaan A and El-Sibai M: Metformin treatment inhibits motility and invasion of glioblastoma cancer cells. Anal Cell Pathol (Amst) 2018: 5917470, 2018.

79. Khoury O, Ghazale N, Stone E, El-Sibai M, Frankel AE and Abi-Habib RJ: Human recombinant arginase I (Co)-PEG5000 [HuArgI (Co)-PEG5000]-induced arginine depletion is selectively cytotoxic to human glioblastoma cells. J Neurooncol 122: 75-85, 2015

80. Dudley ME and Rosenberg SA: Adoptive-cell-transfer therapy for the treatment of patients with cancer. Nat Rev Cancer 3: 666-675, 2003

81. Miao Y, Yang H, Levorse J, Yuan S, Polak L, Sribour M, Singh B, Rosenblum MD and Fuchs E: Adaptive immune resistance emerges from tumor-initiating stem cells. Cell 177: 1172-1186. e14, 2019 
82. Agudo J, Park ES, Rose SA, Alibo E, Sweeney R, Dhainaut M, Kobayashi KS, Sachidanandam R, Baccarini A, Merad M and Brown BD: Quiescent tissue stem cells evade immune surveillance. Immunity 48: 271-285.e5, 2018.

83. Brown JA, Yonekubo Y, Hanson N, Sastre-Perona A, Basin A, Rytlewski JA, Dolgalev I, Meehan S, Tsirigos A, Beronja S and Schober M: TGF- $\beta$-induced quiescence mediates chemoresistance of tumor-propagating cells in squamous cell carcinoma. Cell Stem Cell 21: 650-664.e8, 2017.

84. Tey SK: Adoptive T-cell therapy: Adverse events and safety switches. Clin Transl Immunology 3: e17, 2014.

85. Yang JC: Toxicities associated with adoptive T-cell transfer for cancer. Cancer 21: 506-509, 2015.

86. Miliotou AN and Papadopoulou LC: CAR T-cell therapy: A new era in cancer immunotherapy. Curr Pharm Biotechnol 19 $5-18,2018$.

87. Maeng HM and Berzofsky JA: Strategies for developing and optimizing cancer vaccines. F1000Res 8: F1000 Faculty Rev-654, 2019.

88. Gatti-Mays ME, Redman JM, Collins JM and Bilusic M: Cancer vaccines: Enhanced immunogenic modulation through therapeutic combinations. Hum Vaccines Immunother 13: 2561-2574, 2017.

89. Manthorpe M, Cornefert-Jensen F, Hartikka J, Felgner J, Rundell A, Margalith M and Dwarki V: Gene therapy by intramuscular injection of plasmid DNA: Studies on firefly luciferase gene expression in mice. Hum Gene Ther 4: 419-431, 1993

90. Walters JN, Ferraro B, Duperret EK, Kraynyak KA, Chu J, Saint-Fleur A, Yan J, Levitsky H, Khan AS, Sardesai NY and Weiner DB: A Novel DNA vaccine platform enhances neo-antigen-like T cell responses against WT1 to break tolerance and induce anti-tumor immunity. Mol Ther 25: 976-988, 2017.

91. Lopes A, Vanvarenberg K, Kos Š, Lucas S, Colau D, Van den Eynde B, Préat V and Vandermeulen G: Combination of immune checkpoint blockade with DNA cancer vaccine induces potent antitumor immunity against P815 mastocytoma Sci Rep 8: 15732, 2018

92. Paston SJ, Brentville VA, Symonds P and Durrant LG: Cancer vaccines, adjuvants, and delivery systems. Front Immunol 12 627932,2021

93. Gamat-Huber M, Jeon D, Johnson LE, Moseman JE, Muralidhar A, Potluri HK, Rastogi I, Wargowski E, Zahm CD and McNeel DG: Treatment combinations with DNA vaccines for the treatment of Metastatic Castration-Resistant Prostate Cancer (mCRPC). Cancers (Basel) 12: 2831, 2020.

94. Li L and Petrovsky N: Molecular mechanisms for enhanced DNA vaccine immunogenicity. Expert Rev Vaccines 15 313-329, 2016.

95. Jahanafrooz Z, Baradaran B, Mosafer J, Hashemzaei M, Rezaei T, Mokhtarzadeh A and Hamblin MR: Comparison of DNA and mRNA vaccines against cancer. Drug Discov Today 25: 552-560, 2020.

96. Bhuyan PK, Dallas M, Kraynyak K, Herring T, Morrow M, Boyer J, Duff S, Kim J and Weiner DB: Durability of response to VGX-3100 treatment of HPV16/18 positive cervical HSIL. Hum Vaccin Immunother 17: 1288-1293, 2021.

97. Lopes A, Vandermeulen G and Préat V: Cancer DNA vaccines: Current preclinical and clinical developments and future perspectives. J Exp Clin Cancer Res 38: 146, 2019.

98. Malonis RJ, Lai JR and Vergnolle O: Peptide-based vaccines: Current progress and future challenges. Chem Rev 120 $3210-3229,2020$

99. Li W, Joshi MD, Singhania S, Ramsey KH and Murthy AK: Peptide vaccine: Progress and challenges. Vaccines (Basel) 2: 515-536, 2014

100. Curry JM, Besmer DM, Erick TK, Steuerwald N, Das Roy L, Grover P, Rao S, Nath S, Ferrier JW, Reid RW and Mukherjee P: Indomethacin enhances anti-tumor efficacy of a MUC1 peptide vaccine against breast cancer in MUC1 transgenic mice. PLoS One 14: e0224309, 2019

101. Pan J, Zhang Q, Palen K, Wang L, Qiao L, Johnson B, Sei S, Shoemaker RH, Lubet RA, Wang Y and You M: Potentiation of Kras peptide cancer vaccine by avasimibe, a cholesterol modulator. EBioMedicine 49: 72-81, 2019.

102.Zhang R, Yuan F, Shu Y, Tian Y, Zhou B, Yi L, Zhang X, Ding $\mathrm{Z}, \mathrm{Xu} \mathrm{H}$ and Yang L: Personalized neoantigen-pulsed dendritic cell vaccines show superior immunogenicity to neoantigen-adjuvant vaccines in mouse tumor models. Cancer Immunol Immunother 69: 135-145, 2020.
103. Neek M, Kim TI and Wang SW: Protein-based nanoparticles in cancer vaccine development. Nanomedicine 15: 164-174, 2019.

104. Rousseau RF, Hirschmann-Jax C, Takahashi S and Brenner MK: Cancer vaccines. Hematol Oncol Clin North Am 15: 741-773, 2001.

105. Steinman RM and Cohn ZA: Identification of a novel cell type in peripheral lymphoid organs of mice. I. Morphology, quantitation, tissue distribution. J Exp Med 137: 1142-1162, 1973.

106. Santos PM and Butterfield LH: Dendritic cell-based cancer vaccines. J Immunol 200: 443-449, 2018.

107. Alvarez-Dominguez C, Calderón-Gonzalez R, Terán-Navarro H, Salcines-Cuevas D, Garcia-Castaño A, Freire J, Gomez-Roman J and Rivera F: Dendritic cell therapy in melanoma. Ann Transl Med 5: 386, 2017.

108. de Gruijl TD, van den Eertwegh AJM, Pinedo HM and Scheper RJ: Whole-cell cancer vaccination: From autologous to allogeneic tumor- and dendritic cell-based vaccines. Cancer Immunol Immunother 57: 1569-1577, 2008.

109. Fu C, Zhou L, Mi QS and Jiang A: DC-Based vaccines for cancer immunotherapy. Vaccines (Basel) 8: 706, 2020.

110. Wculek SK, Amores-Iniesta J, Conde-Garrosa R, Khouili SC, Melero I and Sancho D: Effective cancer immunotherapy by natural mouse conventional type-1 dendritic cells bearing dead tumor antigen. J Immunother Cancer 7: 100, 2019.

111. Lai X and Friedman A: Combination therapy of cancer with cancer vaccine and immune checkpoint inhibitors: A mathematical model. PLoS One 12: e0178479, 2017.

112. Anassi E and Ndefo UA: Sipuleucel-T (provenge) injection: The first immunotherapy agent (vaccine) for hormone-refractory prostate cancer. P T 36: 197-202, 2011.

113. Ayoub NM, Al-Shami KM and Yaghan RJ: Immunotherapy for HER2-positive breast cancer: Recent advances and combination therapeutic approaches. Breast Cancer (Dove Med Press) 11: 53-69, 2019

114. Han Q, Wang Y, Pang M and Zhang J: STAT3-blocked whole-cell hepatoma vaccine induces cellular and humoral immune response against HCC. J Exp Clin Cancer Res 36: 156, 2017.

115. Sheikhi A, Jafarzadeh A, Kokhaei P and Hojjat-Farsangi M: Whole tumor cell vaccine adjuvants: Comparing IL-12 to IL-2 and IL-15. Iran J Immunol 13: 148-166, 2016.

116. Xia L, Schrump DS and Gildersleeve JC: Whole-Cell cancer vaccines induce large antibody responses to carbohydrates and glycoproteins. Cell Chem Biol 23: 1515-1525, 2016.

117. Chen G, Gupta R, Petrik S, Laiko M, Leatherman JM, Asquith JM, Daphtary MM, Garrett-Mayer E, Davidson NE, Hirt K, et al: A feasibility study of cyclophosphamide, trastuzumab, and an allogeneic GM-CSF-secreting breast tumor vaccine for HER2+ Metastatic breast cancer. Cancer Immunol Res 2: 949-961, 2014

118. Constantino J, Gomes C, Falcão A, Cruz MT and Neves BM: Antitumor dendritic cell-based vaccines: Lessons from 20 years of clinical trials and future perspectives. Transl Res 168: 74-95, 2016.

119. Köhler G and Milstein C: Continuous cultures of fused cells secreting antibody of predefined specificity. Nature 256: 495-497, 1975

120. Chung S, Lin YL, Reed C, Ng C, Cheng ZJ, Malavasi F, Yang J, Quarmby V and Song A: Characterization of in vitro antibody-dependenT cell-mediated cytotoxicity activity of therapeutic antibodies-impact of effector cells. J Immunol Methods 407: 63-75, 2014

121. Wang W, Erbe AK, Hank JA, Morris ZS and Sondel PM: NK Cell-Mediated Antibody-DependenT cellular cytotoxicity in cancer immunotherapy. Front Immunol 6: 368, 2015.

122. Harris TJ and Drake CG: Primer on tumor immunology and cancer immunotherapy. J Immunother Cancer 1: 12, 2013.

123. Mayor M, Yang N, Sterman D, Jones DR and Adusumilli PS: Immunotherapy for non-small cell lung cancer: Current concepts and clinical trials. Eur J Cardiothorac Surg 49: 1324-1333, 2016

124. Kimiz-Gebologlu I, Gulce-Iz S and Biray-Avci C: Monoclonal antibodies in cancer immunotherapy. Mol Biol Rep 45 2935-2940, 2018.

125. Karlitepe A, Ozalp O and Avci CB: New approaches for cancer immunotherapy. Tumour Biol 36: 4075-4078, 2015.

126. Sathyanarayanan V and Neelapu SS: Cancer immunotherapy: Strategies for personalization and combinatorial approaches Mol Oncol 9: 2043-2053, 2015.

127. Posner J, Barrington P, Brier T and Datta-Mannan A: Monoclona antibodies: Past, present and future. Handb Exp Pharmacol 260: $81-141,2019$ 
128.Zahavi D and Weiner L: Monoclonal Antibodies in Cancer Therapy. Antibodies (Basel) 9: 34, 2020.

129. LoiS, Giobbie-Hurder A,Gombos A,BachelotT,HuiR,CuriglianoG Campone M, Biganzoli L, Bonnefoi $\mathrm{H}$, Jerusalem $\mathrm{G}$, et al: Pembrolizumab plus trastuzumab in trastuzumab-resistant, advanced, HER2-positive breast cancer (PANACEA): A single-arm, multicentre, phase 1b-2 trial. Lancet Oncol 20: 371-382, 2019.

130. ClinicalTrials.gov: A Dose Escalation and Cohort Expansion Study of NKTR-214 in Combination With Nivolumab and Other Anti-Cancer Therapies in Patients With Select Advanced Solid Tumors (PIVOT-02). ClinicalTrials.gov Identifier: NCT02983045. U.S. National Library of Medicine, Bethesda MD, 2016. https://clinicaltrials.gov/ct2/show/NCT02983045. Accessed December 6, 2016.
131. ClinicalTrials.gov: Bempegaldesleukin and Pembrolizumab With or Without Chemotherapy in Locally Advanced or Metastatic Solid Tumors (PROPEL). ClinicalTrials.gov Identifier: NCT03138889. U.S. National Library of Medicine, Bethesda, MD, 2017. https://clinicaltrials.gov/ct2/show/ NCT03138889. Accessed May 3, 2017.

132.Zimmer L, Goldinger SM, Hofmann L, Loquai C, Ugurel S, Thomas I, Schmidgen MI, Gutzmer R, Utikal JS, Göppner D, et al: Neurological, respiratory, musculoskeletal, cardiac and ocular side-effects of anti-PD-1 therapy. Eur J Cancer 60: 210-225, 2016. 